NASA Technical Memorandum 81561

\title{
THE NASA HIGH-SPEED TURBOPROP PROGRAM
}

James F. Dugan, Brent A. Miller, Edwin J. Graber, and David A. Sagerser Lewis Research Center Cleveland, Ohio

Prepared for the

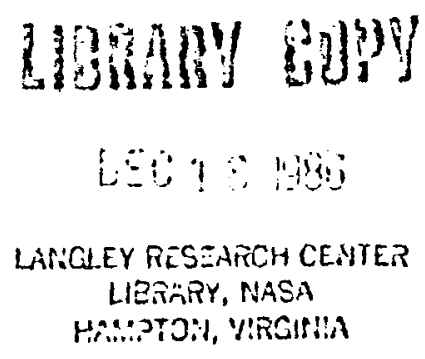

Aerospace Congress

sponsored by the American Society of Automotive Engineers Los Angeles, California, October 13-16, 1980 
THE NASA HIGH-SPEED TURBOPROP PROGRAM

James F. Dugan, Brent A. Miller, Edwin J. Graber, and David A. Sagerser

National Aeronautics and Space Administration

Lewis Research Center

Cleveland, Ohio

\section{SUMMARY}

NASA's Advanced Turboprop Project is a three phased effort initiated in 1978 to provide technology readiness for Mach 0.7 to 0.8 turboprop-powered aircraft with the potential for fuel savings and DOC reductions of up to 30 and 15 percent respectively relative to current in-service aircraft. This paper reviews the status of Phase I in the areas of propeller aeroacoustics, propeller structures, turboprop installed performance, aircraft cabin environment, and turboprop engine and aircraft studies. Current plans to establish large-scale propeller characteristics and to conduct high-speed propeller flight research tests using a modified testbed aircraft are also presented. 
THE MAJOR FEATURES of the advanced high-speed turboprop propulsion system concept are shown in Figure 1. An advanced design propeller would have very thin and highly swept blades to minimize both compressibility losses and propeller noise during high-speed cruise. An area-ruled spinner and an integrated nacelle shape would also be used to minimize compressibility losses in the propeller-blade hub region. Propeller diameter would be kept to a minimum by using 8 to 10 blades with a high propeller power loading. These blades would be constructed using modern propeller blade fabrication techniques. Finally, this advanced propeller would be powered by a large, modern turboshaft engine and gearbox.

The basic reason for the attractiveness of the advanced turboprop concept (sometimes called a prop-fan) is its potential for high propulsive efficiency in the Mach 0.7 to Mach 0.8 speed range, as shown in Figure 2. Older model turboprops had relatively thick, unswept propeller blades and experienced rapid increases in compressibility losses above Mach 0.6. Current high-bypass-ratio turbofans exhibit their highest propulsive efficiency (about 65 percent) at cruise speeds somewhat above Mach 0.8. The advanced turboprop concept is estimated to be about 20 percent more efficient than high-bypass-ratio turbofans at Mach 0.8. At lower cruise speeds, the efficiency advantage of the advanced turboprop is even larger. This high propulsive efficiency of the advanced turboprop makes it an attractive powerplant for many aircraft applications.

Such potential led to the establishment by the National Aeronautics and Space Administration (NASA) of the Advanced Turboprop Project as part of the overall Aircraft Energy Efficiency (ACEE) Program. The objective of the NASA HighSpeed Turboprop Project is to develop the technology for efficient, reliable, and acceptable operation of advanced turboproppowered aircraft at cruise speeds between Mach 0.7 and Mach 0.8 with a cabin comfort level (noise and vibration) comparable to that in modern turbofan-powered aircraft. The turboprop is expected to yield a minimum of 15 percent fuel savings and a 5 percent Direct operating Cost (DOC) improvement relative to turbofans at equivalent levels of technology.

To achieve these goals, a phased Advanced Turboprop Project was started in 1978 by NASA. The major elements are shown in Figure 3. The first element (the propeller-nacelle) is concerned with propeller aerodynamics, acoustics,

Dugan Miller Graber Sagerser 
and structures. The second element addresses the cabin environment. In many installations the turboprop will be mounted on the wing. Since the fuselage would then be in the direct noise field of the propeller, the noise generated by the propeller must be attenuated by the cabin wall in order to provide a lownoise cabin environment. Also, the engine mounts and aircraft structure must be designed to reduce structural borne noise and vibration transmitted to the cabin. The third major element (installation aerodynamics) is concerned with an accelerated, swirling propeller slipstream flowing over the wing for a wingmounted installation. Here, there is the challenge of integrating propeller design with wing design to achieve the best combination of engine efficiency and aircraft lift-drag ratio. Also, airplanes powered by advanced turboprop engines must be configured to have adequate stability and control. The fourth element involves the mechanical components of an advanced turboprop propulsion system: the engine drive, the gearbox, and the advanced propeller. These components must be designed and packaged in such a way that maintenance and reliability will be much improved over that experienced by previous generations of commercial turboproppowered aircraft. Since these four elements are so strongly interrelated, aircraft trade-off studies are performed to obtain the match that will best achieve the goals of low fuel consumption, low operating cost, and passenger acceptance.

The presently planned Advanced Turboprop Project consists of three phases (Fig. 4, Fig. 5). In Phase I (Enabling Technology), a fundamental data base on small scale propeller models is being established by test and analysis. Key analytical and experimental investigations are also underway in fuselage acoustics and installation aerodynamics. Additional effort is devoted to developing advanced analytical and computational techniques in aerodynamics, acoustics, and structural dynamics. This phase also includes studies for concept definition and preliminary design of systems and components to be developed in later program phases. With the initiation of Phase II in 1981, emphasis shifts from small scale model work to design, fabrication, and ground tests (static and wind tunnel) of large diameter $(2.4$ to $3.0 \mathrm{~m}$;

Dugan

Miller Graber Sagerser 
to provide the aircraft integration information required for proper configuration of the flight research aircraft to follow in Phase III. The final phase (Phase III) of the project (System Integration) is scheduled to start in 1985 and will culminate in 1988 with flight research testing of an advanced high-speed propeller on a modified, commercial-type, test-bed aircraft. This flight testing will develop and verify the analytical methodologies, will help resolve problem areas unique to aircraftpropulsion system integration, will establish a data base for future design work, and will provide the confidence required to launch into the design and development of advanced highspeed turboprop-powered aircraft.

\section{STATUS OF PHASE I}

PROPELLER AEROACOUSTIC DESIGN AND PERFORMANCE - A total of five different propeller models are planned for test as part of Phase I of the Advanced Turboprop Project. These models, of about $0.61 \mathrm{~m}(2 \mathrm{ft})$ diameter, are being designed, fabricated, and tested to generate an aerodynamic and acoustic performance data base for advanced high speed propeller design. Information generated will guide the design selection for the large-scale propeller planned for Phase II of the Advanced Turboprop Project.

The design characteristics of the five propeller test models are shown by Figure 6 . The models are designated SR-N, where SR indicates that the model is of a Single Rotation design. Dual rotation, or counter rotation propellers, are not being investigated in the current ACEE program. Four major design variables are listed for each model. The first three propeller models (SR-1, SR-2, and SR-3) differ only in blade tip sweep. The other major variables are held constant, thus the effect of tip sweep on both propeller efficiency and noise generation can be established. These three models have been fabricated and tested, and the blades are shown in Figure 7.

The design variable selection for propeller models SR-5 and SR-6 is more complex than for the first three, with differing values not only for blade sweep but also for design power loading and tip speed. Also, both of these designs

Dugan Miller Graber Sagerser er models. Propeller SR-5 was designed for low noise generation relative to models SR-1, $\mathrm{SR}-2$, and SR-3. This was accomplished by 
increasing hlade sweep to a very high value and by reducing both tip speed and power loading. Model SR-6 is a compromise design between SR-5 and the others. The blade shapes for $S R-5$ and SR-6 are shown by Figure 8 . These propeller models are scheduled for test in late 1980 and early 1981. A propeller model designated as SR-4 using advanced airfoils was deleted from the project due to difficulties in obtaining design data on thin supercritical airfoils. The experimental efficiency obtained with the three eight-bladed models is shown in Figure 9 as a function of flight Mach Number(I)*. Data shown were obtained in the Lewis Research Center $8 \times 6$-foot wind tunnel at $100 \%$ of the design power loading. The benefit of sweep in improving efficiency at high speed is clearly indicated.

A propeller of given design can be operated over a wide range of conditions, with efficiency varying as a function of power loading and tip speed. This efficiency variation at a constant Mach number of 0.8 is shown in Figure 10. For these tests, power loading was varied by changing propeller blade pitch angle. A measured efficiency of about 78.8 percent at a design tip speed of $244 \mathrm{~m} / \mathrm{sec}(800 \mathrm{ft} / \mathrm{sec})$ and a design power loading of $301 \mathrm{~kW} / \mathrm{M}^{2}\left(37.5 \mathrm{hp} / \mathrm{ft}^{2}\right)$ is indicated. A peak efficiency in excess of 80 percent was achieved at lower power loadings and tip speeds (such reductions in power loading and tip speed, however, increase the propeller diameter required for a specific aircraft application, hence increasing propeller and gearbox weight. Thus, in actual design, tradeoffs between performance - based on data such as shown in Figure 10 - and weight are required to establish the optimum aircraft propulsion system design).

Advanced techniques are used in both design and testing of these propeller models. An advanced lifting line aerodynamic analysis is used (Fig. 11) for the propeller (2). For this analysis the propeller wake is represented by a finite number of vortex filaments which are placed along the stream surfaces to conform to the shape of the nacelle. The blades are represented by a curved lifting line simulating the shape of the swept blade. The nacelle can be of any axisymmetric geometry. The flow solution is first found by calculating the inviscid flow around the nacelle. This locates the wake filaments and leads to a calculation of the induced flow and hence the blade section angle of attack. Two-dimensional airfoil and

*Numbers in parentheses designate References at end of paper.

Dugan

Miller Graber Sagerser 
cascade data are then used to compute blade forces. These forces are then resolved into thrust and torque components so that propeller performance can be computed.

To obtain direct measurements of the flow characteristics through and around the propeller blades, a laser velocimeter is being used. A test of this laser system in the Lewis $8 \times 6$-foot wind tunnel is shown by Figure 12. The flow field measurements are used as diagnostic information for further understanding of the propeller model performance data. These laser measurements also serve as a basis for judging the accuracy of advanced aerodynamic analysis programs, such as described by Figure 11. Advanced acoustic design and analysis methods are also being applied to the propeller models. Blade sweep, in addition to providing aerodynamic benefits at high speed, was predicted by analysis to be of benefit in reducing propeller generated noise. Low noise is desired for both the passenger cabin and the community surrounding the airport. An acoustic strip analysis concept was developed by Hamilton Standard and used in the design of several of the propeller models, under contract to NASA-Lewis Research Center. This analysis method is illustrated by Figure 13. As indicated, the method breaks the blade into strips and predicts the generated acoustic pressure for each strip. The resulting sine waves, each with a unique amplitude and phase angle are then added to yield the total resultant acoustic signal. The analytical results indicate that the resultant acoustic pressure can be reduced by proper selection of blade sweep since blade sweep impacts both the amplitude and phase angle of the noise computed for each strip. The results of acoustic tests have confirmed this prediction(3). Shown in Figure 14 is the measured variation with time of the resultant acoustic pressure pulse generated by the straight SR-2 propeller model and by the swept SR-3 propeller. The data were obtained in the Lewis $8 \times 6-$ foot wind tunnel at Mach 0.8 and design power loading and tip speed. The benefit of sweep in reducing the acoustic pressure is clearly evident for the swept model (SR-3) designed using the acoustic method depicted in Figure 13.

The impact of this reduction in acoustic pressure, expressed in terms of the change in sound pressure level measured at the propeller blade passing frequency, is shown by Figure 15.

Dugan Miller Graber Sagerser This data, for the Mach 0.8 design power and tip 
speed condition, indicates a sound pressure level reduction of $6 \mathrm{~dB}$ for the swept SR-3 model as compared to the straight $S R-2$ design. Propeller model SR-1, with a moderate level of sweep, ylelded a noise reduction of about $1 \mathrm{~dB}$. Blade tip Mach number is known to have a strong impact on the noise generated by conventional propellers and is also expected to strongly influence the noise generated by advanced propellers. At Mach 0.8 with a design tip speed of $244 \mathrm{~m} / \mathrm{sec}(800 \mathrm{ft} / \mathrm{sec})$, the relative Mach number at the blade tip is about 1.15 . Propeller noise at this and other tip Mach numbers is shown by Figure 16 for the straight SR-2 propeller and for the swept SR-3 model. These data were obtained in an acoustically treated wind tunnel at a flow Mach number of approximately 0.3 (4). Tip helical Mach number was varied by changing propeller RPM. The tests were conducted with only 2 propeller blades in the disk as opposed to the full eight blades, due to a power limitation in the propeller drive motor. As indicated by Figure 16 sweep was effective in reducing propeller noise over a wide range of tip Mach number. This indicates that blade sweep will be of benefit in reducing noise at the low tip Mach numbers ( 0.7 to 0.9$)$ associated with takeoff and landing, as well as the higher Mach numbers typical of cruise.

The propelier acoustic data obtained to date has been obtained by tests in several different wind tunnels. Acoustic tunnel testing, especially at the higher simulated flight Mach number, is not a mature technology. There is, therefore, an uncertainty in these acoustic test results. To obtain high quality propeller acoustic data, free from unknown wind tunnel effects, flight tests are planned. The model propellers used for the wind tunnel performance tests will be tested in flight using the specially modified NASA JetStar aircraft shown by Figure 17. The model propeller will be powered by an air turbine motor located in a pylon-mounted nacelle on top of the fuselage of the aircraft. The turbine motor is driven by engine bleed air. An array of up to twentyeight flush mounted microphones are installed in the fuselage region near the propeller for measurement of propeller generated near-field noise. Several microphones are also installed on the wing to determine the far-field noise levels. Flight tests are planned to start in

Dugan Miller Graber Sagerser 
PROPELLER STRUCTURES - The aeroacoustic design of advanced high-speed propellers has identified thin, swept-tip blade shapes that are quite different from conventional propellers thus creating new challenges for the blade structural designer. Some of the differences in features between the advanced propellers and conventional propellers, which impact the structural design, are listed in Figure 18. For high-speed performance thin airfoil sections with thickness-to-chord ratios roughly half of more conventional propellers (such as used on the Lockheed Electra aircraft) are necessary. The requirement for aerodynamic sweep necessitates a high taper-ratio to lower the tip mass and reverse sweep at the hub to reduce the overhung moment. The advanced blade also requires a lower aspect ratio (less than half conventional values) along with a greater number of blades, resulting in hub solidities about four times conventional values.

Further differences exist in the flow field in which the blades operate. Relative tip Mach numbers are as much as 30 percent higher than for the Electra design. Advanced turboprops are also likely to be mounted on swept wing or tail surfaces as compared to conventional straight wing installations. The swept wing installation results in blade incidence angle variations in flight which are quite different in frequency content than for straight wing installations (Fig. 19). For a straight wing installation, the propeller plane of rotation is a constant distance from the wing leading edge. As the propeller rotates, the blade incidence angle varies primarily in a once per revolution (1P) cycle due to the wing upwash. For swept wing installations, the distance from the propeller blade to the wing varies with azimuth angle resulting in a more complex flow field with twice per revolution (2P) and higher order (NP) variations $(5,6)$. Although the resulting $1 P$ aerodynamic excitations are still expected to be stronger than the higher order excitations, the higher order excitations may be critical to the blade design because their frequencies may coincide more closely with blade natural frequencies and thus greatly magnify the dynamic response.

The impact of these geometric and flow field differences on the blade design process can be illustrated by reviewing some of the steps involved in determining the blade dynamic

Dugan Miller Graber Sagerser 
flow chart of this analytical process is shown in Figure 20. The design process starts with a desired aeroacoustic blade shape and selected construction concept, materials, and blade retention scheme. The blade natural frequencies, mode shapes, and other inherent structural characteristics are then estimated. In the past, this analysis was accomplished with beam-type methods which were satisfactory for straight, high-aspect-ratio blades. For the swept, low-aspect-ratio, advanced blade, finite-element methods are required to achieve necessary accuracy. The expected use of multielement composite structures will further increase the complexity of this step.

A definition of the aircraft installation and operating conditions is then used, along with the blade shape, to evaluate the blade uns teady aerodynamic loads or excitations. Except for foreign object impact, unsteady mechanical loads are not expected to dominate blade design. In the past, aerodynamic excitations have been calculated using fairly simple methods which assume subsonic flow over a straight wing with blade pressure forces distributed on a lifting line. With the swept wing, transonic flow field, and advanced blade shape, more sophisticated methods may be required to adequately define the unsteady pressure forces. The blade structural model together with the aerodynamic excitations then allow the vibratory stress levels to be determined.

Based on the calculated natural frequencies and mode shapes, and the aerodynamic excitations, the blade stability boundaries may be estimated. In the past, only stall flutter at takeoff conditions was a primary design concern. Stall. flutter problems were avoided by using semi-empirical design methods based on data from conventional propellers with straight, high-aspect-ratio blades. For the advanced propeller, a new data base or experimentally verified analytic methods may be required. At cruise conditions, the higher speeds and thinner blades of the advanced propeller make classical flutter a potential stability problem. Analyses have indicated that classical flutter will not be encountered in the expected operating range (7). This conclusion, however, has been supported by test data only to the extent that flutter was not observed during performance tests of the two-foot propeller models.

Dugan Miller Graber Sagerser

Because of the increased complexity of the advanced propellers, design methods for predicting blade dynamic response and stability, 
developed for conventional propeller blade shapes and operating conditions, may not be adequate. An experimental evaluation of available design methods is therefore needed to assess their adequacy and define needed improvements. To accomplish this, a number of tests are planned, (and have been initiated) by NASA, as outlined in Figure 21, to investigate aerodynamic excitations, classical flutter, and stall flutter. Propeller models $S R-2 C, S R-3$, and $S R-5$, which have a range of blade planform shapes, will be used. SR-2C is a graphite-epoxy composite version of the SR-2 aerodynamic shape. $S R-3$ and $S R-5$ are solid titanium. Although these models were designed for aerodynamic and acoustic testing and are not dynamically scaled from a full-size design, they do have the proper aeroacoustic shape and will allow comparison of prediction to experimental results.

To investigate aerodynamic excitations, the three propeller models will initially be tested with an isolated nacelle at angle of attack conditions to get baseline response to a simple $1 \mathrm{P}$ flow disturbance. These tests are currently being conducted in the NASA-Lewis Research Center $8 \times 6$ foot Wind Tunnel. Tests of models $S R-2 C$ and $S R-3$ have been completed and tests of model SR-5 will begin late in 1980 . The SR-2C model is shown installed in the wind tunnel at angle of attack in Figure 22. This same model will later be tested with a semispan aircraft model (nacelle, wing, fuselage) to measure its response to a realistic flow field. This test will be done as part of an installation aerodynamics test at NASA-Ames Research Center.

Classical flutter data will also be taken during the isolated nacelle testing at Lewis. In these tests blade damping coefficients will be determined from strain gauge measurements at various propeller and wind tunnel velocities. Flutter boundaries will then be defined by extrapolation and compared to prediction. Two methods of exciting the blades are being evaluated. The first method uses the random turbulence present in the tunnel airflow, as described in reference 8 . The second method uses air jets directed at the blades to excite the blades. Initial tests are now underway to evaluate and develop these two techniques.

Stall flutter tests will also be conducted with an isolated nacelle and will be accomplished both statically and at low speeds. Stall

Dugan Miller Graber Sagerser flutter has occurred with conventional propeller 
designs at static conditions. However, some analyses suggest that the advanced propeller may be more susceptible to stall flutter at low speeds. Thus, both regimes will be investigated during the tests, both forward and reverse thrust blade angles will be evaluated. While the propeller model excitation and flutter tests are proceeding, NASA is also sponsoring a structural design study of large propeller blades (NAS3-22394, Hamilton Standard). The objectives of this study are to: (1) define structural concepts for full-scale advanced propeller blades, (2) determine the structural tradeoffs involved with different blade configurations, (3) identify new design, analysis, or fabrication techniques which may be required for tinese blades, and (4) define a development plan to acquire the necessary technology. The scope of the effort is shown on Figure 23.

Four blade configurations are being investigated in this study: SR-2 ( 8 blades), SR-3 ( 8 blades), SR-3 ( 10 blades), and SR-5 (10 blades). The 10-bladed SR-3 configuration has the same blade planform as the 8-bladed SR-3 configuration except the blade chord distribution is reduced by the ratio of $8 / 10$. The analysis of the 8-bladed SR-3 configuration in this study represents an update of a previous study conducted by Hamilton Standard (7). For configuration SR-5, two structural concepts will be evaluated. For comparability, all configurations will be designed with a diameter of 11 feet and a tip speed of $800 \mathrm{ft} / \mathrm{sec}$. The initial efforts in the study are to define the design requirements for advanced high-speed propeller blades (e.g., aerodynamic excitations and foreign object damage limits) and to evaluate and recommend structural concepts for each of the configurations for further design analysis. A number of potential structural concepts were considered, as shown in Figure 24. In general, the hollow concepts were favored over the solid concepts because they are lighter in weight. They also offer greater flexibility in design. Of the hollow concepts, the spar and shell design was recommended primarily because the spar, which is the main structural component, is protected from damage by the shell. The spar/shell concept is also expected to offer greater design flexibility and lower manufacturing costs over the monocoque concepts. Within the spar/shell concept category, further choices are open in the design of the spar, shell, and fill elements, as indicated in the figure.

Dugan Miller Graber Sagerser 
The recommended structural concepts for each of the blade configurations is summarized in Figure 25. Selection of materials for the SR-5 configurations will be made after more preliminary analysis. Further design analysis will be conducted on each of the configurations to define their characteristics and allow the structural tradeoffs with blade shape to be determined. For one of the configurations, the design of a small-scale aeroelastic model will be evaluated to determine its feasibility and value to the development of a large-scale blade.

PROPELLER INSTALLED PERFORMANCE - The integration of advanced high-speed highly-loaded propellers with the swept, supercritical wings of future transport aircraft is one of the fundamental technical issues addressed in the Advanced Turboprop Project. At the high cruise Mach numbers being considered, aerodynamic interactions between the wing and turboprop propulsion system could significantly reduce both propeller efficiency and wing performance, resulting in a serious erosion of the fuel savings advantage offered by the turboprop (an alternative configuration that avoids this problem is to mount the turboprop system on the tail or on a pylon in the tail area). Such configurations are being evaluated as part of the aircraft trade studies. Factors to be considered in evaluating wing installation losses are illustrated in Figure 26.

Any nonuniformity in the flow at the propeller plane, such as that generated by the upstream flow adjustment to a swept, lifting wing, can result in a net reduction of propeller efficiency. The swirling, accelerated flow (produced by the highly-loaded propellers) washing over a supercritical wing can both increase scrubbing drag and move the wing into drag-rise. Aerodynamic interference between the wing and nacelle flow fields can also increase aircraft drag. On the positive side, it is possible that the wing if properly tailored - could act as a propeller stator and recover a portion of the propeller thrust being lost to swirl. Currently, the magnitude of each of these factors, and their combined effect, is subject to much speculation. Because of this uncertainty, the magnitude of the above installation losses is being experimentally and analytically assessed as part of the Phase I program.

An initial evaluation of the propeller slipstream interaction with a swept supercritical

Dugan Miller Graber Sagerser wing was provided in a 1976 wind tunnel test, 
using a slipstream simulator. In these tests, reported in detail in reference 9, a strutmounted ejector was used to create the swirling, accelerated flow of a propeller slipstream over a wing/body model, as illustrated in Figure 27. Wing angle of attack, slipstream swirl angle, and slipstream Mach number increment were varied parametrically during testing, at cruise Mach numbers from 0.70 to 0.84 . Swirl was found to be the dominant factor in both the force and pressure data. The resultant effect of swirl and Mach number on aircraft cruise drag is shown in Figure 27 for swirl angles from 0 to 11 degrees. The penalties associated with swirl were found to be considerably less than initially anticipated. In fact, at 11 degrees of swirl, a favorable drag increment was indicated. Unfortunately, the physical presence of the ejector hardware upstream of the wing created a localized flow disturbance which could have significantly influenced the test results. Also, the absence of the nacelle on the wing tended to make the flow simulation unrealistic. Thus, further verification of these results is required.

A second wind tunnel test is planned for late 1980 to provide a better definition of the magnitude and source of propeller/slipstream/ nacelle/wing interactions. In these tests, a propeller-powered semi-span model of an advanced swept wing transport will be tested in the Ames 14 -ft Wind Tunnel as shown schematically in Figure 28. The swept wing is of the same design as that used in the swirl simulator testing (9), and the nacelle design was selected based on RECAT study results (10-14). The propeller model $(.62 \mathrm{~m} ; 24.5$ in-diameter) is a composite version of the SR-2 design; actual propeller design is not believed to be critical for this test since the propeller is merely a means of providing the swirling flow field over a wing/nacelle combination. An air turbine, mounted inside the nacelle, is used to power the propeller. This turbine uses facility supplied high-pressure air which enters the model through the wing root and passes to the turbine through channels in the wing and nacelle. Remote control of the air pressure and temperature allows regulation of turbine speed during testing. The turbine is instrumented to allow calculation of $\mathrm{rpm}$, air flow rate, and horsepower.

Propeller swirl and loading can be varied by adjusting blade speed and angle. Blade angle

Dugan Miller Graber Sagerser 
can be adjusted continuously during testing. The entire semi-span aircraft model angle-ofattack is also adjustable during testing. This allows testing over a wide range of propeller blade excitations. The aeroelastic response of the propeller blades will be monitored using two strain-gaged blades. Signals from the strain-gages will be transmitted from the rotating plane using a slip-ring assembly located on the aft region of the nacelle. Over 360 static pressures will be positioned on the wing and nacelle surfaces (Fig. 29) to provide data on the source of the installation drag increments. These measurements will be sufficiently detailed to allow isolation of areas where interference pressures are strongest.

Testing will be conducted over a range of cruise Mach numbers from 0.5 to 0.82 , and for a wide range of aircraft angles of attack, propeller blade angles, and propeller rotational speeds. The resultant data will be used in the development of an improved computer code for analyzing the propeller slipstream flow over a wing and nacelle. Analysis of test data will be used to define wing and nacelle modifications which offer the potential for reduced installation losses. The first modification planned for this model will be limited to changes in the wing leading edge geometry along with minor wing and nacelle recontouring (thus not altering the basic wing structure). This revised configuration will be tested in late-1981 in the Ames 11-ft Wind Tunnel to verify the predicted improved installation characteristics. In Phase II of the Advanced Turboprop Project, an optimized wing/nacelle will be designed, fabricated, and tested to confirm the feasibility of a minimum installation loss, wing-mounted configuation. Data from all of these tests will be used in the continuing development of advanced techniques for analyzing propeller and airframe interactions. A table is presented in Figure 30 illustrating the progression of analytical capability from the linear panel codes capable of handling only simple geometrics, to fully transonic codes capable of computing the flow around complex geometrics. Development of these computer codes is proceeding in parallel with model design and testing. AIRCRAFT CABIN ENVIRONMENT - Passenger cabin environment (i.e., noise level and Graber Sagerser vibration) was improved when propeller driven aircraft were replaced by the early turbojet 
and turbofan aircraft. Since that time there has been a continuing improvement in cabin comfort particularly with the introduction of high-bypass-ratio turbofan engines and wide body aircraft. A return to the cabin noise level and vibration of the propeller aircraft era would be a step backward, and would likely be resisted by the flying public. An advanced turboprop aircraft must therefore offer a cabin environment comparable to today's turbofan aircraft. Accordingly, one of the major technology objectives of the Advanced Turboprop Project is to identify means for reducing cabin noise and vibration levels with minimum cost and weight penalty to the aircraft.

Figure 31 illustrates several potential sources of cabin noise and vibration. The airborne path for noise from the propeller and engine to the cabin wall is of obvious concern. High noise levels striking the fuselage wall will be felt by the passengers as both vibration and noise. Past efforts at quieting propeller driven aircraft have generally focused on this transmission path. A structural borne path for cabin noise and vibration is also indicated by Figure 31 . Potential sources for these structural excitations are the propeller, gearbox, engine, and the propeller wake striking the nacelle and wing. Tailoring of engine mount design has been used in the past to suppress vibrations transmitted to the airframe. However, little work has been done to determine the contribution of the propeller wake impinging on the airframe (or wing) to cabin noise and vibration levels.

A number of approaches and techniques are available for designing an advanced turboprop aircraft to have a good cabin environment. Several of these are listed on Figure 32. During the course of the Advanced Turboprop Project each of these items will be examined to determine its potential. It is probable that an optimized aircraft design will employ many of these techniques in order to obtain the desired passenger cabin environment, with minimum cost and weight penalty to the aircraft. The propeller noise reduction required at cruise to reach the cabin noise level goal is illustrated by Figure 33. For simplicity, this figure assumes that the governing transmission path for cabin noise is the airborne path from the propeller blade, through the airspace to the fuselage skin, and then through the fuselage

Dugan

Miller

Graber Sagerser sidewall to the cabin interior. For illustration purposes, a cabin noise goal of $75 \mathrm{dBA}$ is shown which corresponds to a sound pressure level of $90 \mathrm{~dB}$ at a propeller blade passing 
frequency of $160 \mathrm{HX}$. Existing aircraft fuselage sidewalls, with conventional acoustic treatment, will yield a noise reduction of about $20 \mathrm{~dB}$ for this frequency. Thus, with an interior noise goal of $90 \mathrm{~dB}$, an exterior sound pressure level of about $110 \mathrm{~dB}$ can be tolerated if existing fuselage sidewalls are assumed. However, the projected minimum propeller sound pressure level striking the fuselage, for a wing-mounted installation, is estimated to be about $135 \mathrm{~dB}$. An additional $25 \mathrm{~dB}$ of propeller noise attenuation must therefore be obtained if the cabin noise level goal is to be achieved. This would be accomplished through various aircraft design trades, as indicated on Figure 33.

A detailed knowledge of the acoustic field striking the fuselage skin is required in order to design the most efficient sidewall. Previously, the test and analysis methods underway in Phase I of the Advanced Turboprop Project, to define propeller noise levels, were discussed. Figure 34 illustrates an additional test that was conducted to specifically define the acoustic field on a curved surface simulating a fuselage wall. These "boilerplate" fuselage wall tests were conducted in an anechoic wind tunnel using the SR-3 propeller test model as a noise source. Data obtained from flush-mounted microphones were used to generate contours of constant sound pressure level on the simulated fuselage as illustrated by the figure. Data were also obtained to determine the phase characteristic of the incident acoustic field. These data, along with the results of other acoustic tests and analysis work, are being used to aid in the design of efficient, high attenuation, fuselage sidewalls.

As part of the Phase I program, fuselage acoustic design studies $(15,16)$ were conducted by the Lockheed-California Company and by Bolt Beranek and Newman. A brief summary of these study results is shown by Figure 35 . For these studies an interior noise goal of $80 \mathrm{dBA}$ was assumed. Study results indicate that this goal should be achieveable using a double wall fuselage concept which retains conventional aluminum fuselage structure as the load carrying members. Both studies indicated that experimental work must be conducted to validate the fuselage design concept. Work is now underway to obtain such experimental information as part of the Phase I program.

Dugan Miller Graber Sagerser 
The plot at the bottom of Figure 35 shows the acoustic weight penalty, expressed as a percent of aircraft gross weight, required to meet the $80 \mathrm{dBA}$ cabin noise goal for a range of aircraft types and gross weights. The highest acoustic weight penalty, computed to be about $2.3 \%$ of aircraft gross weight, was computed by Lockheed for a four engine wide body aircraft. This weight penalty is about equal to that used by Lockheed in a previous study of advanced turboprop aircraft where a fuel savings in excess of $17 \%$ was indicated, as compared to a turbofan aircraft. This latest fuselage acoustic design study thus supports the level of acoustic weight penalties used in previous studies of advanced turboprop powered aircraft, where significant fuel savings were projected.

The double wall fuselage design concept, identified as most attractive by both of the fuselage study contracts, is illustrated by Figure 36. The primary difference between this concept and present fuselage sidewall design is in the mass of the interior trim panel. With the double wall concept the mass of the trim panel is increased so that it is comparable to that of the outer wall. This, along with careful selection of the fiberglass filler, vibration isolator, and depth of the air gap, is projected to result in a high noise attenuation sidewall. Total wall thickness, or depth, of this concept may be greater than that of a conventional fuselage, which could be a disadvantage.

Although ground based model tests are planned (for 1981) to investigate the potential of this fuselage wall design concept, flight tests with a large scale aircraft will finally be required in order to generate and validate the technology for meeting the passenger cabin noise and vibration goals. Several of the methods to be employed for noise reduction, and their interactions, can not be adequately simulated by ground-based tests. AIRCRAFT AND ENGINE STUDIES - A number of aircraft studies have been conducted to quantify the benefits promised by the advanced turboprop (10-14, 17-20). In every study, the airplanes powered by advanced turboprops used less fuel than competing turbofan-powered airplanes. These studies are generally summarized in Figure 37, where the trend in fuel savings with aircraft design range is shown. For short-haul aircraft, where takeoff and descent dominate the

Dugan Miller Graber Sagerser fuel fraction, the turboprop fuel savings can be as high as 30 percent. For medium-range aircraft, fuel savings are 15 to 20 percent. For very long-range aircraft, where cruise dominates 
the fuel fraction, turboprop fuel savings are 17 to 30 percent. These fuel savings for the turboprop are relative to a turbofan-powered aircraft with the same level of component technology. Thus, if a new turbofan engine would achieve a 15 percent fuel savings over a conventional turbofan in a new medium-range transport, a new turboprop with the same level of engine component technology could achieve a 30 to 35 percent fuel savings. It is this very large fuel savings potential that prompted NASA to include the Advanced Turboprop Project in its ACEE program.

The most recent study is reported in reference 20. Under contract to NASA, Douglas Aircraft Company studied turboprop-powered derivatives of its turbofan-powered DC-9 Super 80 which first flew in 1979. After screening a number of different installation configurations, the three shown in Figure 38 were selected for a more detailed evaluation. These three are (1) wing-mount, (2) tail-mount, and (3) pylon-mount. The fuel savings of these turboprop-powered Super 80 derivatives, relative to the turbofan-powered Super 80 , are shown in Figure 39. At the longer stage lengths, the fuel savings are 22 to 25 percent. At the shorter stage lengths, fuel savings are somewhat higher, 24 to 27 percent. A significant result is that the two aircraft with aft-mounted turboprops are competitive with the wing mount configuation. Thus, at this time, both wing-mounted and aft-mounted turboprops are viable candidates for fuel efficient commercial transport aircraft.

MECHANICAL COMPONENTS - The fourth major element in the Advanced Turboprop Project involves the mechanical components of the turboprop system. This element was of particular concern at the beginning of the project because of the high maintenance costs for the turboprop propulsion system on the Electra, and the general feeling that turbofan maintenance costs would always be substantially lower. For this reason, the Lewis Research Center placed a contract (NAS3-20057) with Detroit Diesel Allison (with Hamilton Standard as a subcontractor) to evaluate the Electra system (21). Allison, of course, was the manufacturer of the turboprop system for the Electra. Results (Fig. 40) indicated that the 1960-era turboprop maintenance costs were indeed higher than those for the JT8D turbofan (a representative turbofan), but the difference was mainly in the core engine. The core engine

Dugan Miller Graber Sagerser 
of the turboprop was expensive to maintain largely because it was an older technology core originally designed for military application: A second major conclusion was that overall advanced-turboprop maintenance costs can be competitive with those of an advanced turbofan. Core maintenance costs, based on equal levels of technology, should be about equal. Preliminary conceptual designs were made by Allison to evaluate how turboprop maintenance costs could be reduced. The maintenance costs of the advanced propeller and gearbox were shown to be greatly improved by performing on-condition maintenance instead of scheduled overhauls, by using modular construction, and by emphasizing simplicity and reliability in design.

\section{CURRENT PLANS FOR PHASES II AND III}

The presently planned Advanced Turboprop Project, consisting of three phases, will culminate in 1988 with flight research testing of an advanced high-speed propeller on a modified commercial-type aircraft. A summary overview of the entire three-phase project, as currently planned, is shown by Figure 41 .

The content of the Phase I Enabling Technology effort was described in detail by the previous section of this paper. In summary, this phase, to be completed the end of this year, will establish a fundamental performance data base through analysis and test of smallscale propellers. Key analytical and experimental investigations are also underway in fuselage acoustics and installations aerodynamics. Additional effort is devoted to developing advanced analytical and computational techniques in aerodynamics, acoustics, and structural analysis and dynamics. This phase also includes studies for concept definition and preliminary design of systems and components to be developed by later phases. With the initiation of Phase II of the program in 1981, emphasis shifts from smallscale model work to design, fabrication, and ground tests (static and wind tunnel) of a large-scale (2.4 to $3.0 \mathrm{~m}$; 8 to $10-\mathrm{ft}$ diameter) propeller. Note from Figure 41 that work is continued in fuselage acoustics and installation aerodynamics in this phase in order to have the required aircraft integration information to properly configure the flight research aircraft to follow in Phase III. Program definition

Dugan

Miller Graber Sagerser studies and tests are now underway in Phase I to define the desired design characteristics and 
testing methods and options for the large propeller to be built and tested during Phase II. Propeller definition will be completed by about mid-1981. The large-scale blade and disk tecinology effort is scheduled to start in 1981, leading to fabrication of the first blade approximately two years later. Development tests of blade specimens and completed blades and disks start in 1982 and will run parallel to the fabrication effort through about mid-1984. The first propeller assembly is expected to be available early in 1984. This blade technology development effort would be followed by static rotor tests using an existing ground based propeller drive system. The propeller is then installed on the gas turbine propeller drive system which will be a modification of an existing shaft engine along with a new nacelle and modified gearbox. This propulsion system will then be used for check-out static tests, low-speed wind tunnel tests, and high-speed wind tunnel tests.

The pacing item in the Phase II program is the blade technology effort, as opposed to acquiring the modified shaft engine to power the propeller, or any of the other necessary (but relatively low risk) efforts required before propeller testing can begin. As mentioned previously, there is a continuation in Phase II of the aircraft integration work in both installation aerodynamics and fuselage acoustics. Two additional aerodynamic integration tests are planned (in addition to the one test in Phase I) to determine an optimized configuration for an under-the-wing nacelle design that would yield minimum drag. In fuselage acoustics, existing turboprop aircraft will be used, if feasible, to validate the fuselage acoustic analytical design methods now under development in Phase I. An optimized ground test model will also be tested. This will be followed by a preliminary design study effort to determine the characteristics of an aircraft fuselage employing the advanced acoustic concepts. There is also a continuing study action planned for Phase II to investigate advanced components and concepts. Studies of advanced core engines will be performed to define requirements for such future engines and to define requirements for the gearbox. Following this effort, preliminary design layouts of a modern gearbox and pitch-change mechanism will be made. There will also be continued development of improved aerodynamic, acoustic, and structural dynamic analytical capabilities and concepts during the Phase II time period.

Dugan

Miller Graber Sagerser 
Phase III of the program, Systems Integration, is scheduled to start in 1985. This final phase combines the work of the previous phases and will result in flight testing of an advanced propeller on a modified commercial-type test-bed aircraft in 1988. (The existing engines of the test-bed aircraft would be retained so that the propeller would not be the prime source of aircraft thrust.) The propeller and propeller drive system to be used for this flight research program would be the same one to be used during the static and wind tunnel tests of Phase II.

The Phase III test-bed aircraft flight tests will further develop and verify the various technologies of the advanced turboprop concept, will investigate those problem areas that are unique to integration of the concept on the aircraft, will establish a technology data base for future design, and will provide the required confidence by industry for their future incorporation of advanced turboprops into new aircraft applications. The following key areas will be evaluated during the flight tests: (1) propeller structural integrity and structural dynamics at high- and low-speed when operating in the flow field generated by a swept wing, under realistic operational conditions, (2) propeller generated near-field and far-field noise, (3) propeller and flowfield induced static and dynamic loads on the nacelle and airframe, (4) passenger cabin noise and vibration levels, and effects of fuselage at tenuation concepts on such noise, and (5) installed propulsive efficiency where consideration is given to aerodynamic interactions between the propeller, nacelle, pylon and wing (as a verification of predicted results from wind tunnel testing). Ground-based rig tests of an advanced gearbox and pitch change system suitable for an engine in the 15,000 SHP class are also planned for the Phase III. Such tests would establish feasibility of the design approach and would provide initial verification of design reliability and durability.

\section{CONCLUDING REMARKS}

Dugan

Miller

Graber

The high-speed advanced turboprop concept

Sagerser holds the promise of major improvements in fuel consumption and DOC for future subsonic commercial transport aircraft. It was this potential which prompted NASA to include the Advanced Turboprop Project as a major element in 
1ts Aircraft Energy Efficiency program. Two such commerctal airplanes are shown in the top part of Figure 42: a medium-range wide-body transport with four turboprops mounted on the wing, and a shorter-range narrow-body transport with two turboprops mounted at the rear of the fuselage. Other subsonic aircraft, which, also can benefit by using the propfan concept, are cargo airplanes and the military patrol aircraft as shown at the bottom of Figure 42 .

For these aircraft, operational capability is required at speeds up to Mach 0.7 to 0.8 . It is this requirement that distinguishes the advanced turboprops from Electra-type turboprops which were designed to operate at speeds up to about Mach 0.62. At the higher cruise speeds, thinner, swept-tip, highly-loaded, multi-bladed propellers must be used. Such propeller systems introduce unique problems in the areas of structural dynamics, installation, aerodynamics, acoustics, and gearbox/pitchchange systems. These technologies are all addressed in the NASA Advanced Turboprop Project with a goal of providing technology readiness by the late $1980^{\prime} \mathrm{s}$.

As fuel prices continue to rise at a dramatic rate - from 40 cents a gallon in 1978 when the turboprop project was initiated to over twice that now (Fig. 43) - the need for introducing the fuel efficient turboprop into the commercial aircraft fleet becomes more and more pressing. The Advanced Turboprop Project is expected to provide the technology and confidence for commercial acceptance of this advanced concept, thus helping to offset the impact of rising fuel costs on aircraft operation.

\section{REFERENCES}

1. R. J. Jeracki, D. C. Mikkelson, and B. J. Blaha, "Wind Tunnel Performance of Four Energy Efficient Propellers Designed for Mach 0.8 Cruise." NASA TM-79124, April 1979.

2. L. J. Bober, and G. A. Mitchel1, "Summary of Advanced Methods for Predicting High Speed Propeller Performance." AIAA Paper 80-0225, January 1980.

3. J. H. Dittmar, R. J. Jeracki, and B. J. Blaha, "Tone Noise of Three Supersonic Helical Tip Speed Propellers In a Wind Tunnel." NASA TM-79167, June 1979.

4. B. M. Brooks, and F. B. Metzger, "Acoustic Test and Analysis of Three Advanced

Dugan Miller Graber Sagerser Turboprop Models." (Hamilton Standard; NASA Contract NAS3-20614), NASA CR-159667, January 1980. 
5. J. P. Mendoza, "Interference Effects of Aircraft Components on the Local Blade Angle of Attack of a Wing-Mounted Propeller." NASA TM-78587, June 1979 .

6. R. W. Cornell, and E. A. Rothmall, "Structural Design and Analysis of Prop-Fan Blades." AIAA Paper 79-1116, June 1979.

7. J. F. Dugan, B. S. Gatzen, and W. M. Adamson, "Prop-Fan Propulsion - Its Status and Potentia1." SAE Paper 78095, November 1978.

8. C. E. Hammond, and R. V. Doggett, "Determination of Subcritical Damping by Moving-Block/Randomdec Applications." NASA SP-145, October 1975.

9. H. R. Welge, and J. P. Crowder, "Simulated Propeller Slipstream Effects on a Supercritical Wing." (Douglas Aircraft Company; NASA Contract NAS2-9472.) NASA CR152138, June 1978.

10. J. P. Hopkins, and H. E. Wharton, "Study of the Cost/Benefit Tradeoffs for Reducing the Energy Consumption of the Commercial Air Transportation System." (LR27769-1, Lockheed-California Co.; NASA Contract NAS2-8612.) NASA CR-137927, 1976.

11. J. P. Hopkins, "Study of the Cost/ Benefit Tradeoffs for Reducing the Energy Consumption of the Commercial Air Transportation Sys tem." (LR-27769-2, Lockheed-California Co.; NASA Contract NAS2-8612.) NASA CR-137926, 1976.

12. E. F. Kraus, "Cost/Benefit Tradeoffs for Reducing the Energy Consumption of Comnercial Air Transportation System. Vol. I: Technical Analysis." (MDC-J7340-Vol.-1, Douglas Aircraft Co., Inc.; NASA Contract NAS2-8618.) NASA CR-137923, 1976. J. C. Van Abkoude, "Cost/Benefit Tradeoffs for Reducing the Energy Consumption of Commercial Air Transportation System. Vol. II: Market and Economic Analyses." (MDC-J7340-Vo1.-2, Douglas Aircraft Co., Inc.; NASA Contract NAS2-8618.) NASA CR-137925, 1976.

13. "Energy Consumption Characteristics of Transports Using the Prop-Fan Concept: Summary." (D6-75780, Boeing Commercial Airplane Co.; NASA Contract NAS2-9104.) NASA CR-137938, 1976.

14. "Energy Consumption Characteristics of Transports Using the Prop-Fan Concept: Final Report." (D6-75780, Boeing Commercial Airplane Co.; NASA Contract NAS2-9104.) NASA CR-137937, 1976.

15. D. C. Rennison, J. F. Wilby, A. H.

Dugan

Miller Graber Sagerser Marsh, and E. G. Wilby, "Interior Noise Control Prediction Study for High-Speed PropellerDriven Aircraft." (Bolt Beranek and Newman, 
Inc.; NASA Contract NAS1-15426.) NASA CR159200, September 1979.

16. J. D. Revell, F. J. Balena, and L. R. Koval, "Analytical Study of Interior Noise Control by Fuselage Design Techniques on High-Speed, Propeller-Driven Aircraft." (Lockheed-California Company; NASA Contract NAS1-15427.) NASA CR-159222, July 1978.

17. R. E. Neitzel, R. Hirschkron, and R. P. Johnston, "Study of Unconventional Aircraft Engines Designed for Low Energy Consumption." (R76AEG597, General Electric Co.; NASA Contract NAS3-19519.) NASA CR-135136, 1976.

18. D. E. Gray, "Study of Unconventional Aircraft Engines Designed for Low Energy Consumption." (PWA-5434, Pratt \& Whitney Aircraft; NASA Contract NAS3-19465.) NASA CR$135065,1976$.

19. J. D. Revel1, and R. H. Tullis, "Fuel Conservation Merits of Advanced Turboprop Transport Aircraft." (LR28283, LockheedCalifornia Company; NASA Contract NAS2-8612.) NASA CR-152096, 1977.

20. I. M. Goldsmith, and J. V. Bowles, "Potential Benefits for Propfan Technology on Derivatives of Future Short-To-Medium-Range Transport Aircraft." AIAA Paper 80-1090, June 1980 .

21. "Study of Turboprop Systems Reliability and Maintenance Costs." (EDR 9132, Detroit Diesel Allison; NASA Contract NAS320057.) NASA CR-135192, 1978. 


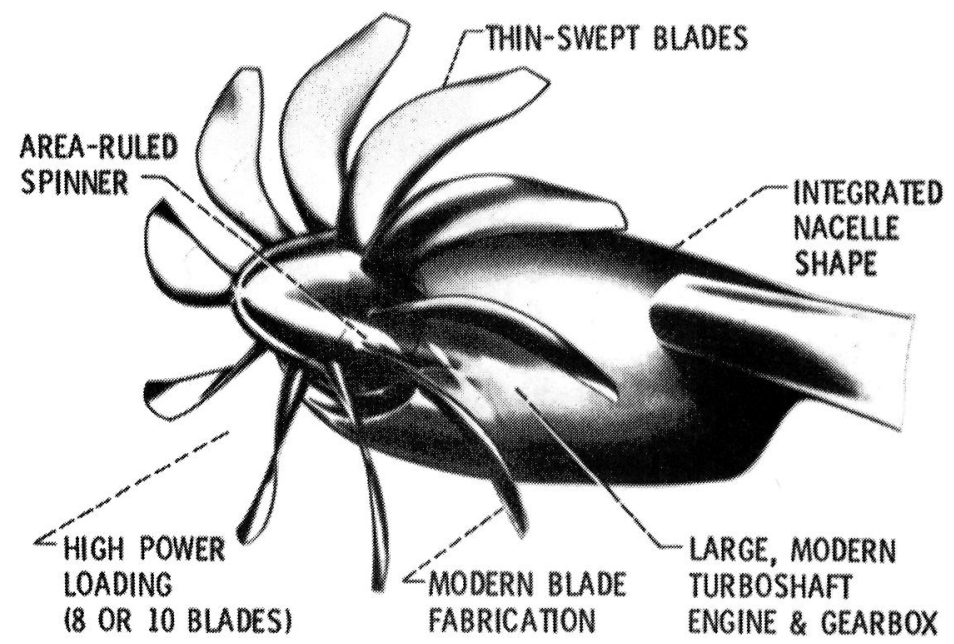

Figure 1. - Advanced turboprop propulsion system.

CS-79-2165

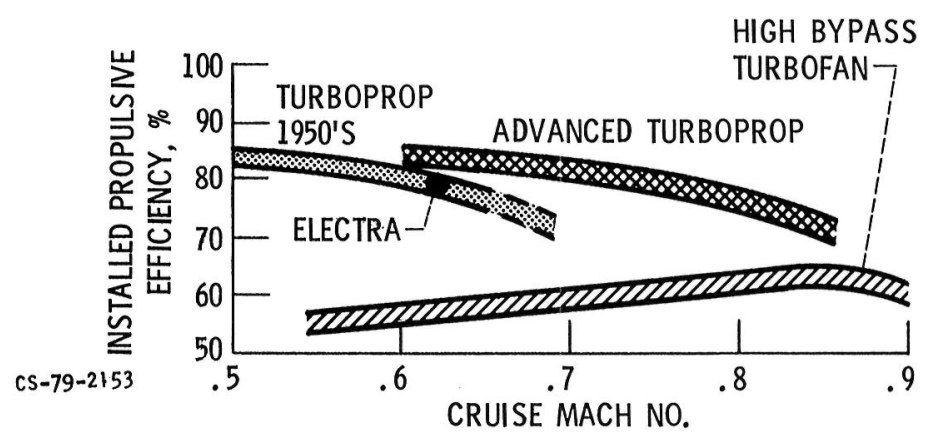

Figure 2. - Installed propul sive efficiency at cruise. 


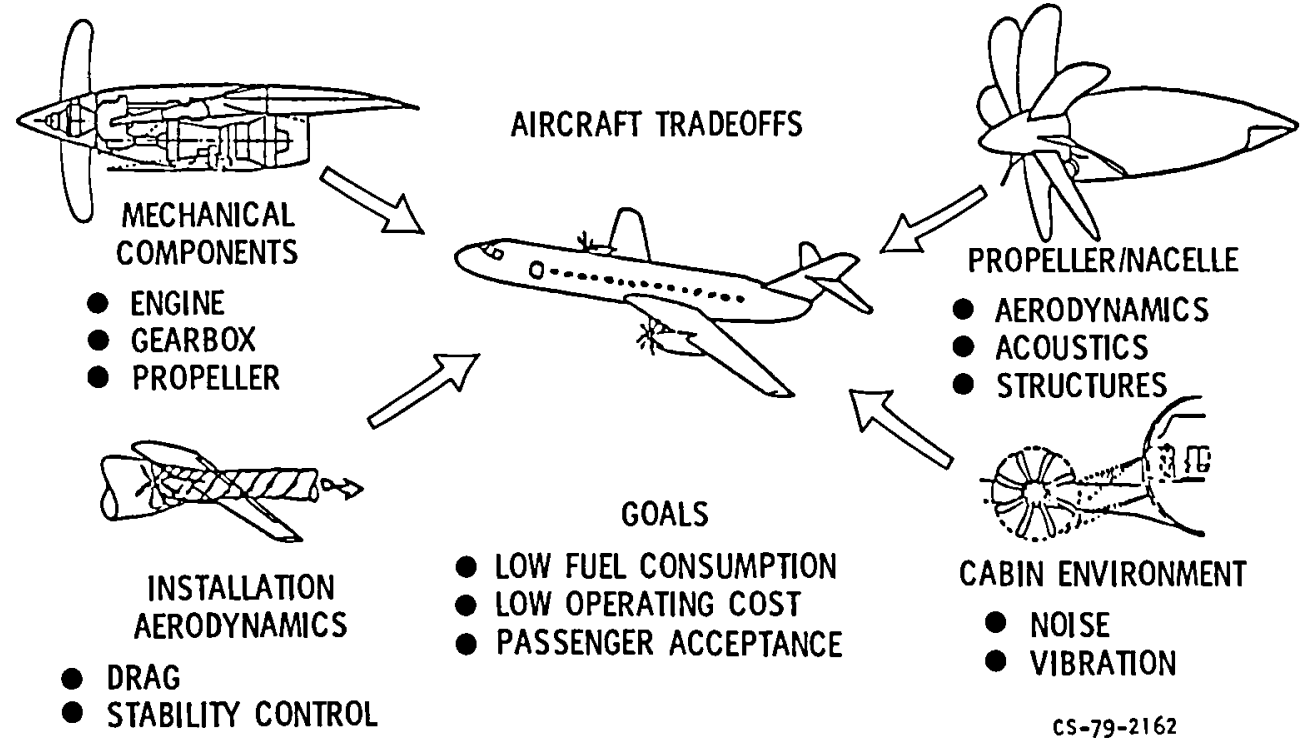

Figure 3. - Advanced turboprop project.

PHASE I: ENABLING TECHNOLOGY

- DEVELOP FUndAMENTAL DATA BASE ON SMALL-SCALE MODELS AND ESTABLISH CONCEPT FEASIBILITY

PHASE II: LARGE-SCALE STRUCTURES

- ESTABLISH STRUCTURAL INTEGRITY OF LARGE-SCALE HIGH-S PEED PROPELLERS OF ADVANCED AEROACOUSTIC DESIGN

PHASE III: SYSTEM INTEGRATION

- ESTABLISH FULLY INSTALLED FLIGHT PERFORMANCE AND OPERATIONAL CHARACTERISTICS AND DEMONSTRATE ACCEPTABLE CABIN ACOUSTICS

Figure 4. - Major phase objectives - advanced turboprop project. 


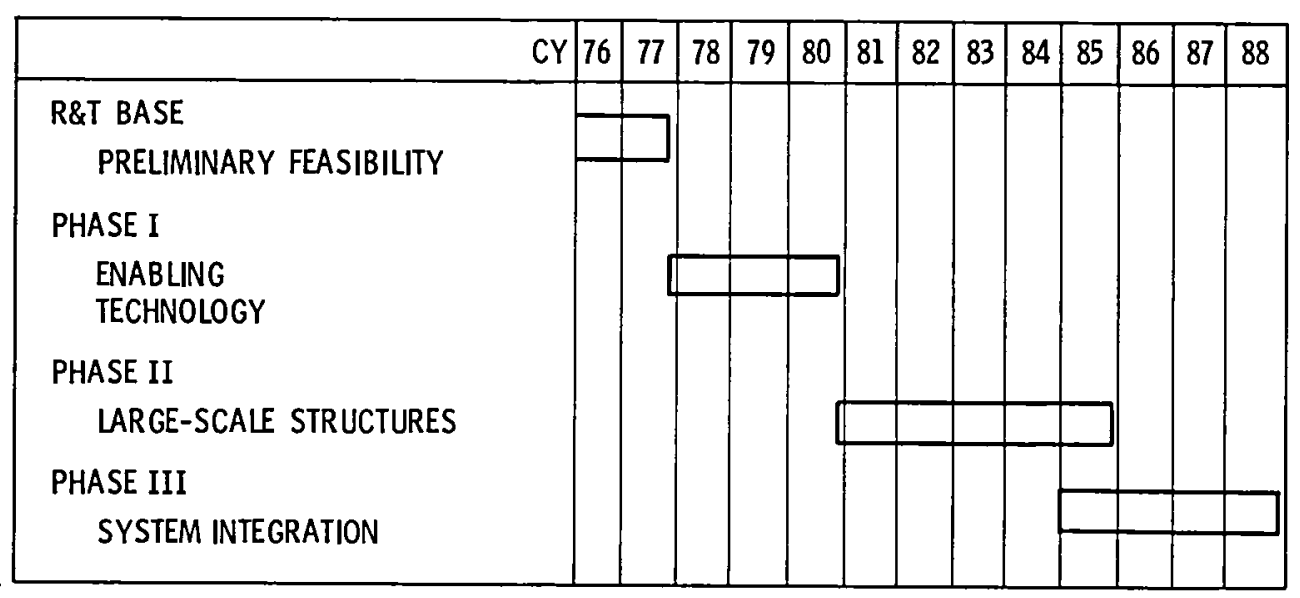

Figure 5. - NASA Advanced turboprop program schedule.

SR-1 SR-2 SR-3 SR-5 SR-6

$\begin{array}{llllll}\text { TIP SWEEP, DEG } & 23 & 0 & 35 & 48 & 31\end{array}$

$\begin{array}{llllll}\text { NO. BLADES } & 8 & 8 & 8 & 10 & 10\end{array}$

$\begin{array}{llllll}\text { POWER LOADING } & 37.5 & 37.5 & 37.5 & 26 & 30\end{array}$

$\begin{array}{llllll}\text { TIP SPEED, FPS } & 800 & 800 & 800 & 600 & 700\end{array}$

Figure 6.- Design matrix of propeller test models. 


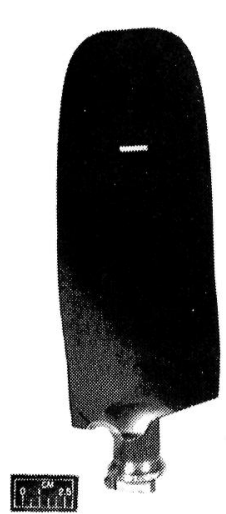

$S R-2$

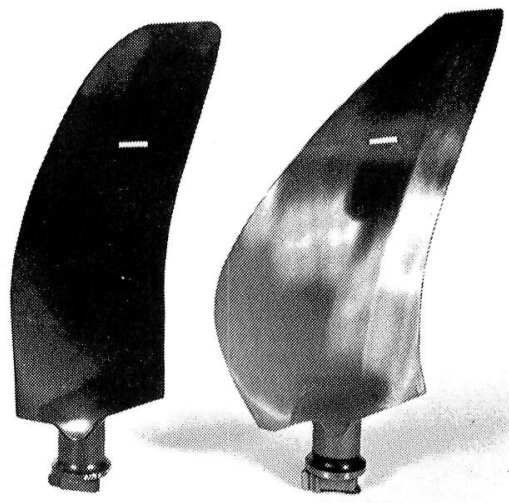

SR-1

SR-3 CS-79-2164

Figure 7. - Photograph of blades from three small-scale eight-bladed advanced propellers.

SR-6

10 BLADES

$V_{T}=700$ FPS

$S H P / D^{2}=30$

SWEEP $=31^{\circ}$

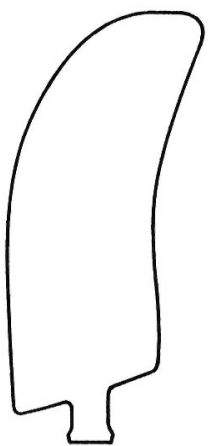

SR -5

10 BLADES

IMPROVED AERO/ACOUSTIC

PLANFORM

$\mathrm{V}_{\mathrm{T}}=600 \mathrm{FPS}$

$S H P / D^{2}=26$

SWEEP $=48^{\circ}$

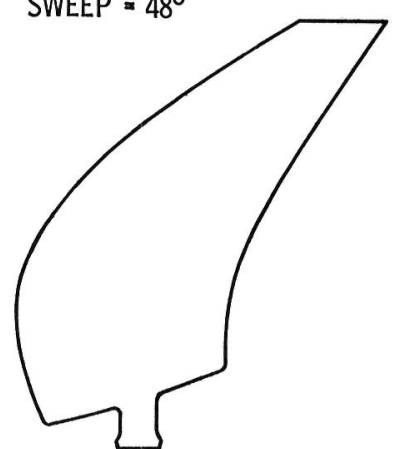

Figure 8. - Design features of two small-scale ten-bladed advanced propellers. 


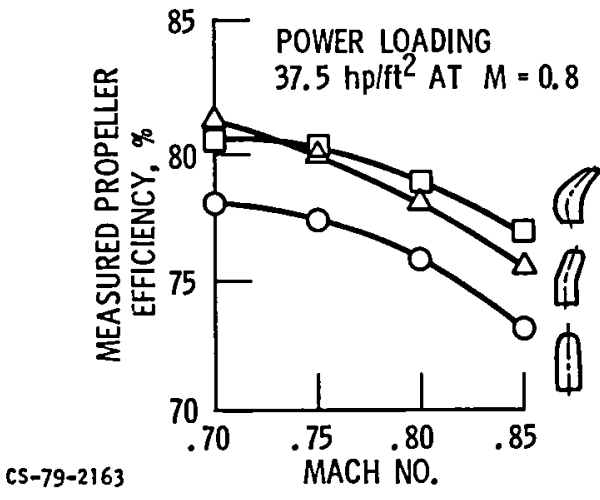

Figure 9. - Effect of blade sweep and Mach number on measured propeller efficiency. Lewis $8 \times 6$ Wind Tunnel.

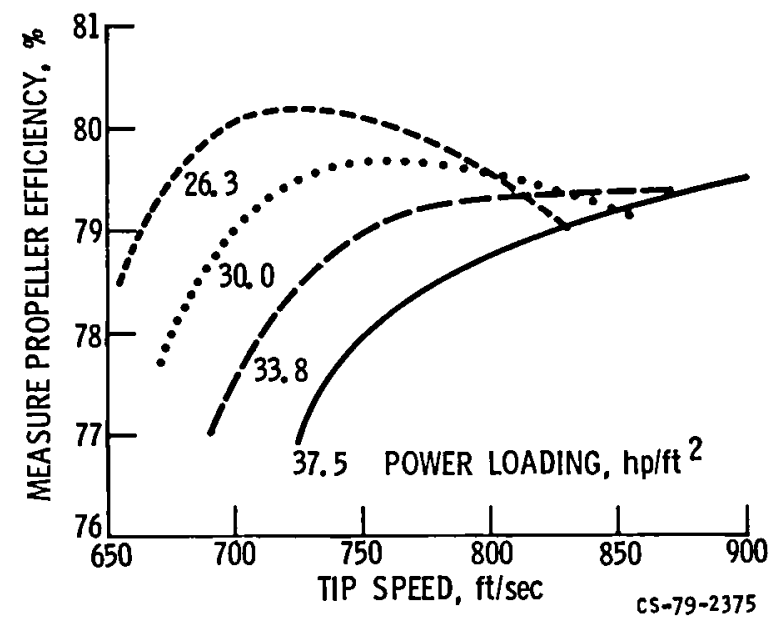

Figure 10. - Effect of power loading and tip speed on measured efficiency of propeller model SR-3 at Mach 0. 8. Lewis $8 \times 6$ Wind Tunnel. 
MODEL

WAKE - VORTEX FILAMENTS ALONG STREAM SURFACES

SINGLE OR COUNTER ROTATION

BLADES - CURVED LIFTING LINE

NACELLE - ARBITRARY GEOMETRY

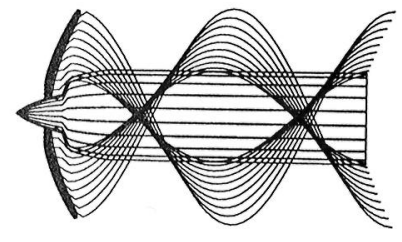

SOLUTION TECHNIQUE

INVISCID NACELLE SOLUTION TO

LOCATE WAKE FILAMENTS

INDUCED ANGLE OF ATTACK DUE TO WAKE

BLADE FORCES USED IN

CIRCUMFERENTIALLY AVERAGED

VISCOUS FLOW

Figure 11. - Summary of important features of the propeller nacelle interaction analysis.

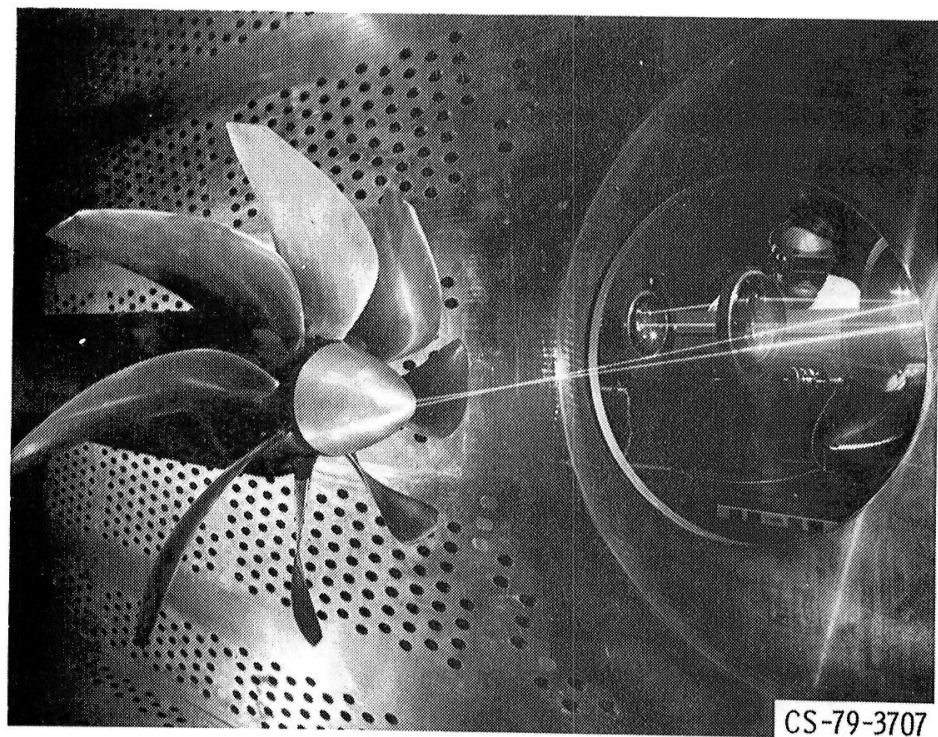

Figure 12. - Laser velocimeter in NASA-Lewis Research Center 8- by 6-Foot Wind Tunnel for making detailed flow measurements to be used in verifying advanced analyses. 


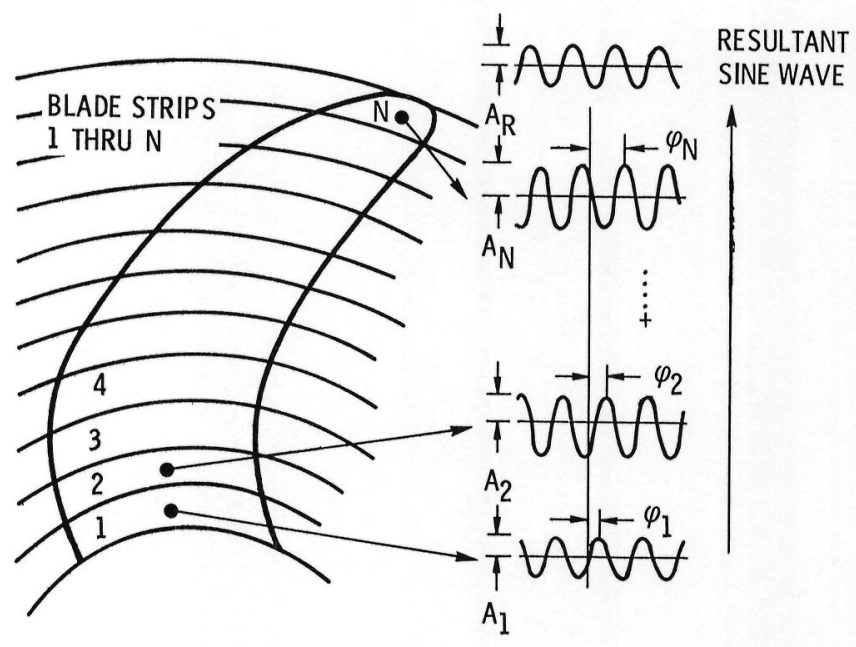

Figure 13. - Acoustic strip analysis concept developed by Hamilton Standard for propeller design and noise predictions.

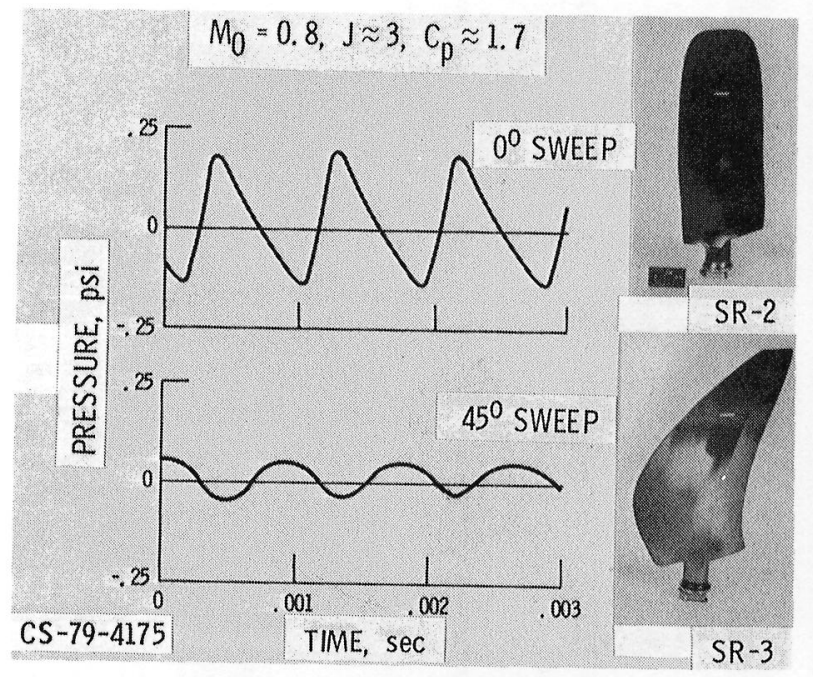

Figure 14. - Effect of sweep on measured near field acoustic pressure. 


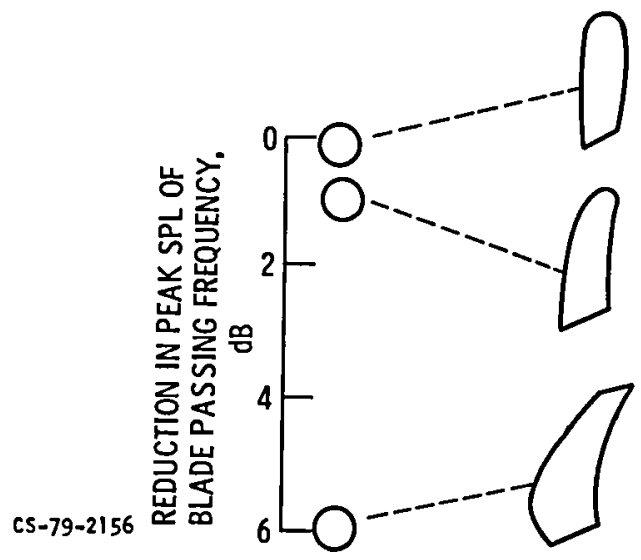

Figure 15. - Noise comparison of three propeller models. Lewis $8 \times 6$ Wind Tunnel. Mach 0.8 design conditions.

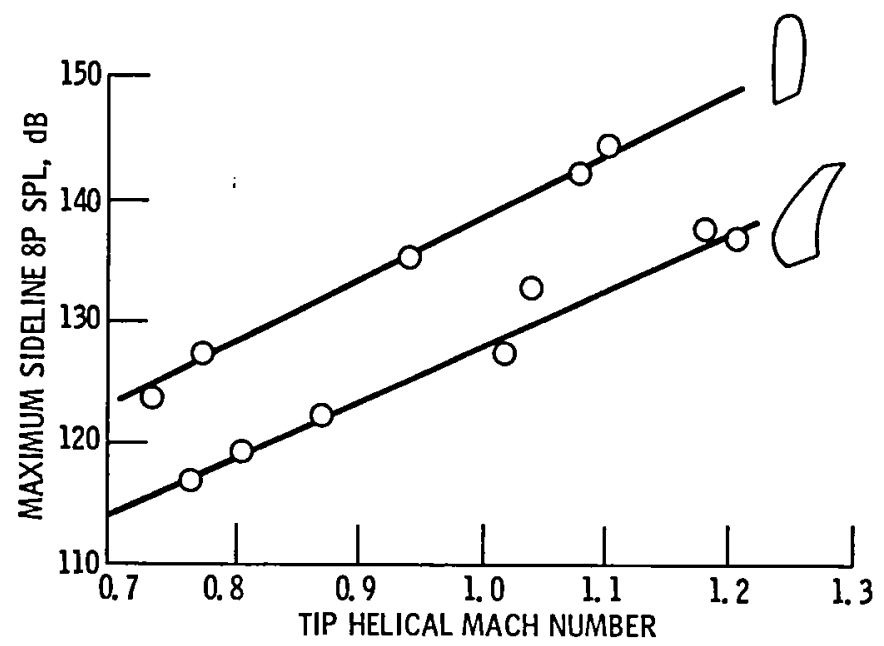

Figure 16. - Effect of blade design and tip Mach number on propeller noise generation. Near field acoustic test data. Test with two blades, Mach 0.3 forward speed. 


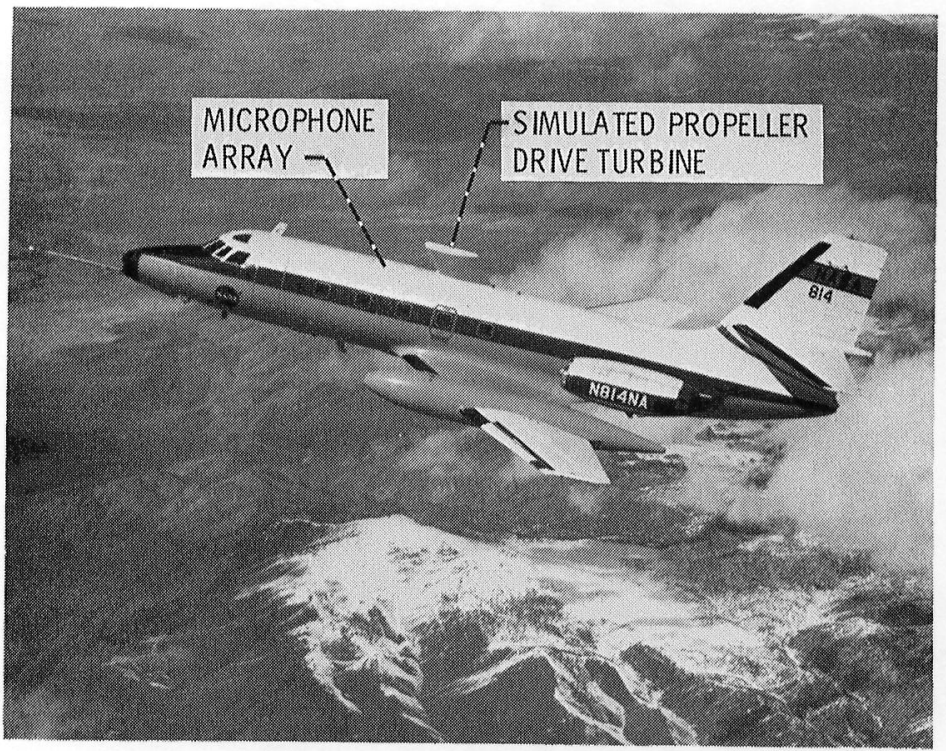

Figure 17. - NASA Jetstar aircraft modified for propeller acoustic flight tests.

\section{GEOMETRIC}

THIN, HIGH-SPEED AIRFOILS

BLADE SWEEP

(2\% vs APPROX. $4 \% \mathrm{t} / \mathrm{c}$ )

LOW ASPECT RATIO

$\left(20^{\circ}-50^{\circ}\right.$ vs $\left.0^{\circ}\right)$

HIGH SOLIDITY

(APPROX. 4 vs APPROX. 10)

(APPROX. 2 vs APPROX, 0.50)

\section{FLOW FIELD}

TRANSONIC TIP SPEED

$(M=1.1$ vs APPROX. 0.9)

MOUNTED ON SWEPT WING

(2P vs IP EXCITATION)

Figure 18. - Unconventional features of the advanced propeller design. 
STRAIGHT WING AIRCRAFT

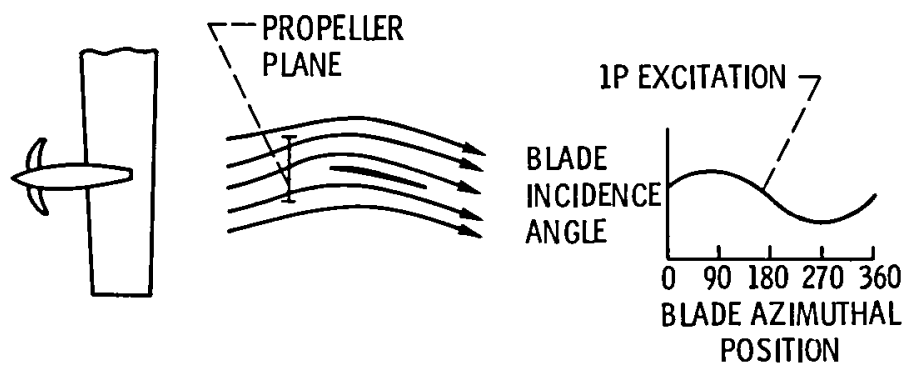

SWEPT WING AIRCRAFT

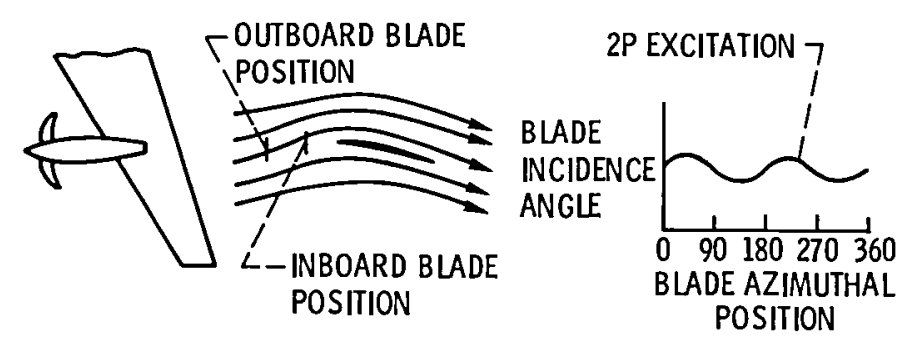

Figure 19. - Effect of swept wing installation on in-flight propeller aerodynamic excitation.

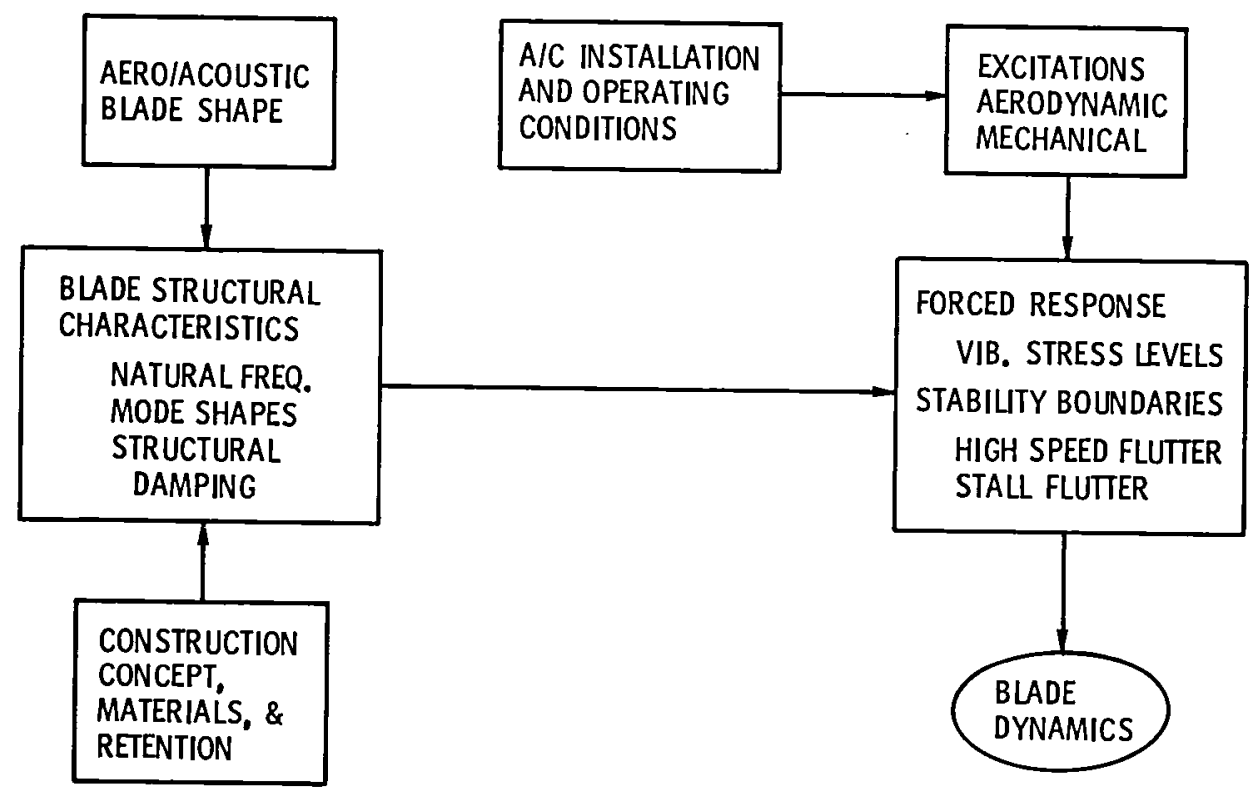

Figure 20. - Steps to determine propeller blade dynamic characteristics. 
OBJECTIVES

ASSESS ADEQUACY OF CURRENT DESIGN/ANALYSIS METHODS

- IDENTIFY CRITICAL PROBIEM AREAS

APPROACH

TEST ARTICLES

- 2-FOOT AERO/ACOUSTIC MODELS (SR-2C, SR-3, SR-5)

AERODYNAMIC EXCITATIONS

- ISOLATED NACELLE WITH ANGLE OF ATTACK: BASELINE RESPONSE (IP EXCITATIONS)

- NACELLE/NING: RESPONSE TO INSTALLED

FLOWFIELD (1 + NP EXCITATIONS)

HIGH SPEED (CLASSICAL) FLUTTER

- ISOLATED NACELIE

STALL FLUTTER

- ISOLATED NACELIE

- static and low speed tests

- FORWARD AND REVERSE THRUST

Figure 21. - Outline of planned and on-going propeller aeroelastic tests.

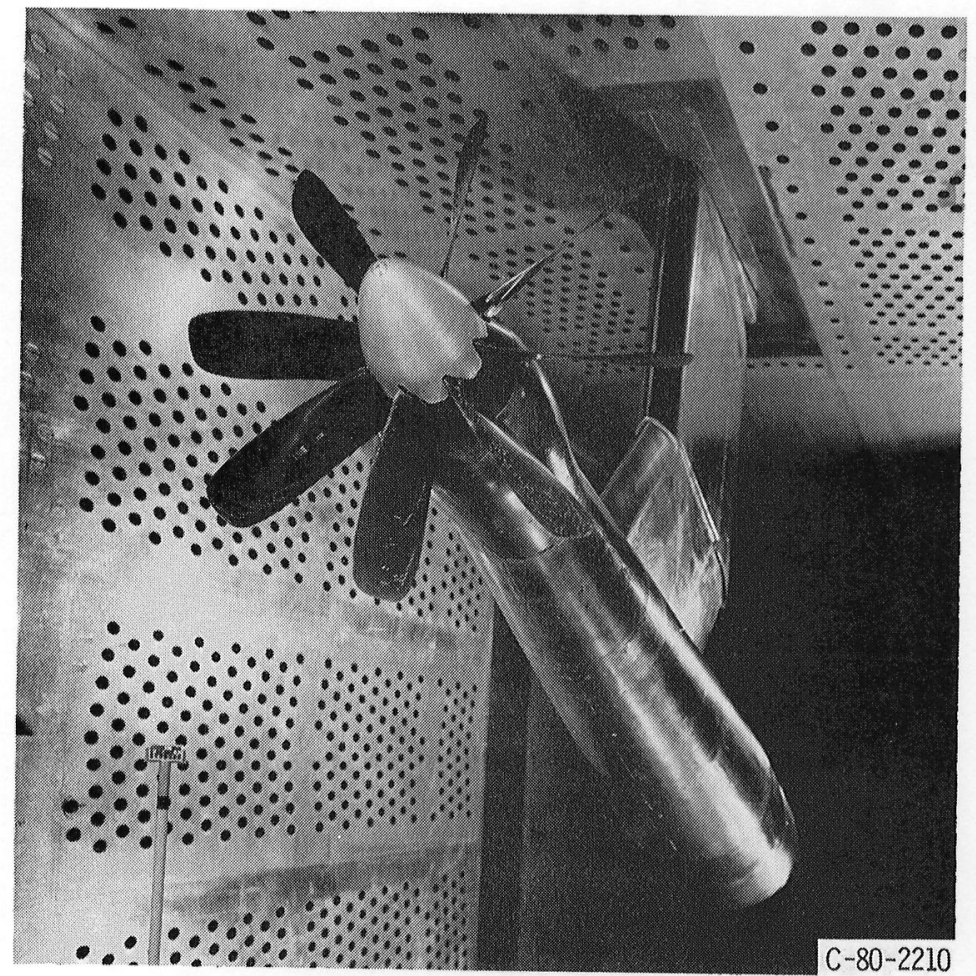

Figure 22. - Aeroelastic test of propeller model SR-2C in NASA-Lewis Research Center 8- by 6-foot Wind Tunnel. 
- DESIGN REQUIREMENTS

- four blade configurations

- two fabrication CONCEPTS

- aEROELASTIC MODEL fEASIBILITY

- TECHNOLOGY DEVELOPMENT PLAN

Figure 23. - Large scale propeller blade structural design study NAS3-22394, Ham. Std. I.
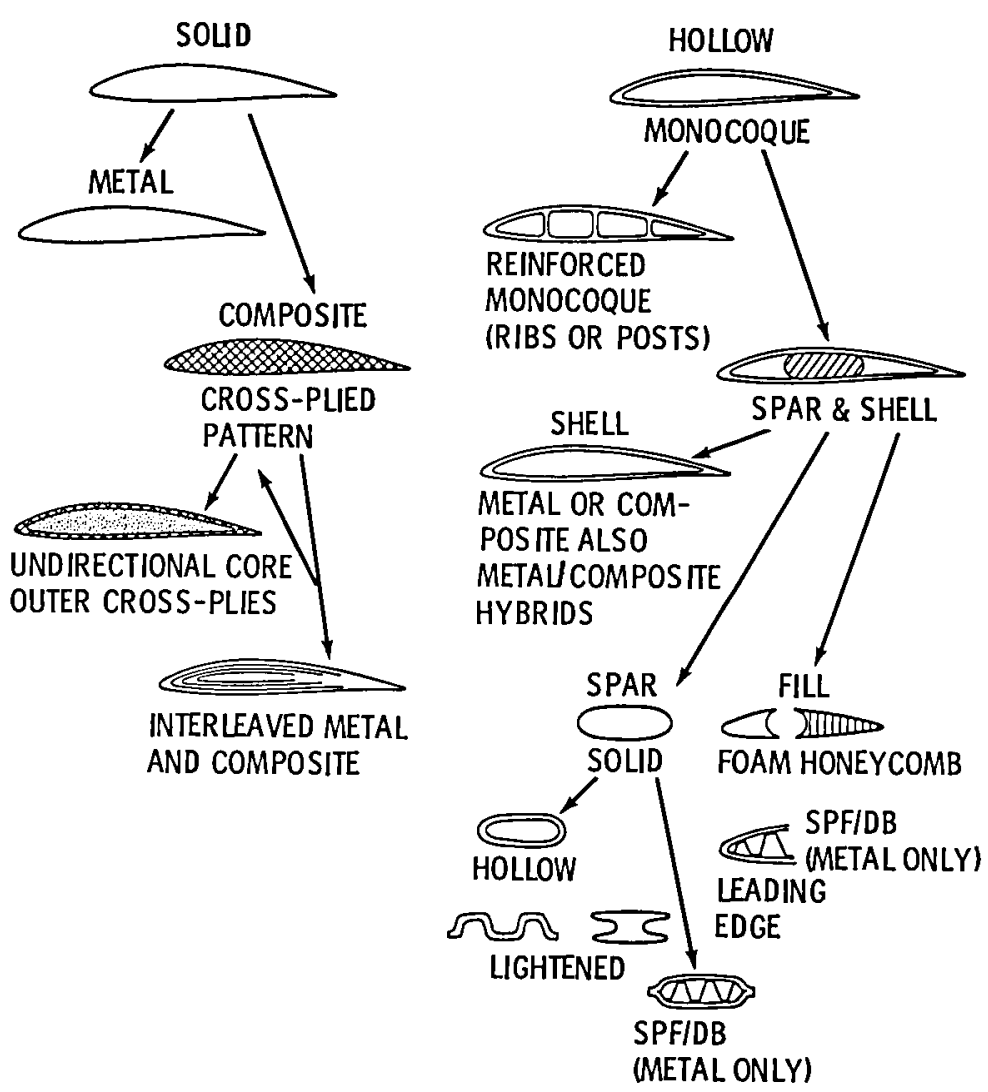

Figure 24. - Structural concepts evaluated in large scale propeller blade structural design study. 


$\begin{array}{lll}\text { SR-2 (8 way) } & \begin{array}{l}\text { HOLLOW } \\ \text { STEEL }\end{array} & \text { FIBERGLASS } \\ \text { SR-3 (8 way) } & \text { SOLID } & \\ & \text { ALUMINUM } & \text { FIBERGLASS }\end{array}$

$\begin{array}{ll}\text { SR-3 (10 way) SOLID } & \text { FIBERGLASS } \\ & \text { ALUMINUM }\end{array}$

$\begin{array}{lll}\text { SR }-5 \text { (10 way) } & \text { METAL } & \text { COMPOSITE } \\ & \text { COMPOSITE } & \text { COMPOSITE }\end{array}$

Figure 25. - Propeller blade structural concepts recommended for further analysis.

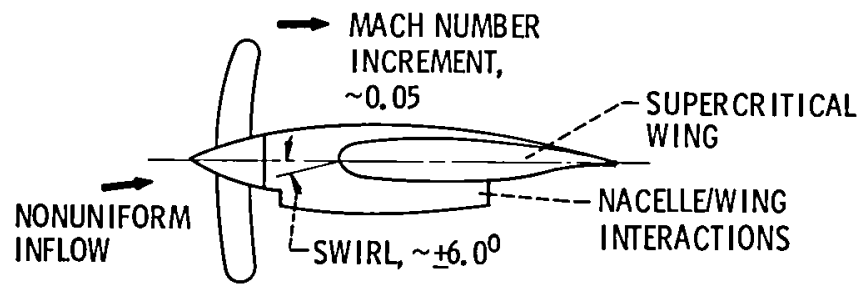

- ASSESS MAGNITUDE OF AERODYNAMIC INTERFERENCE

- UNDERSTAND AERODYNAMIC PHENOMENA

- DEVELOP ANALYTICAL \& EXPER IMENTAL DATA BASE

- USE SLIPSTREAM SIMULATOR \& POWERED SEMISPAN MODEL

$$
\text { CS-78-257 }
$$

Figure 26. - Major elements of airframe - propulsion system integration program. 


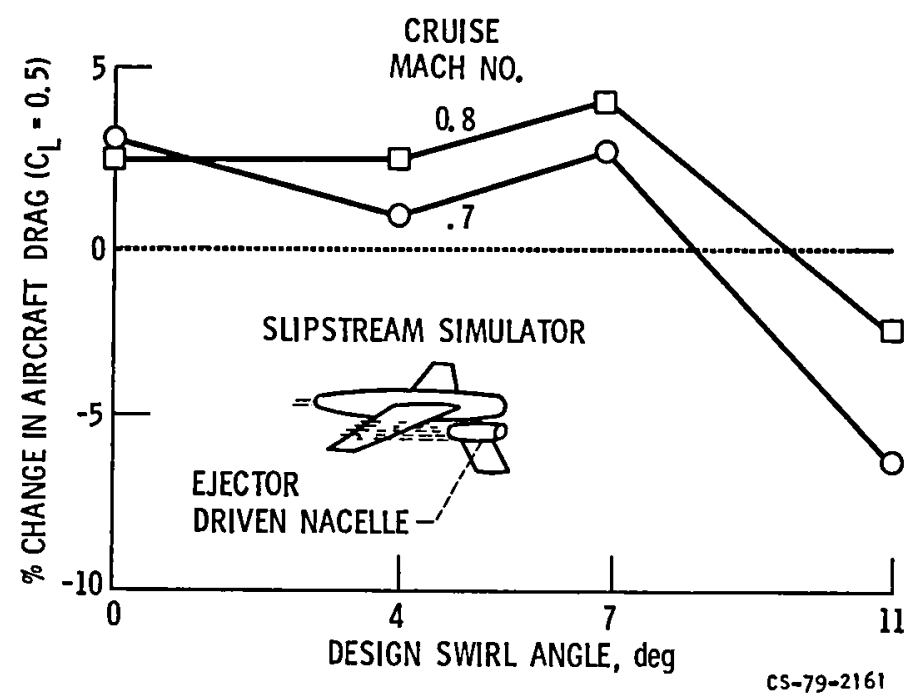

Figure 27. - Slipstream simulator test results.

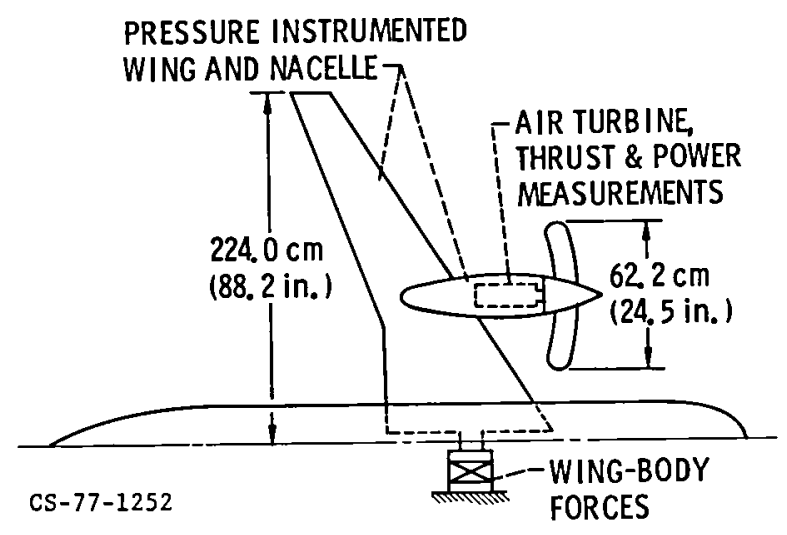

Figure 28. - Semi-span model concept. 


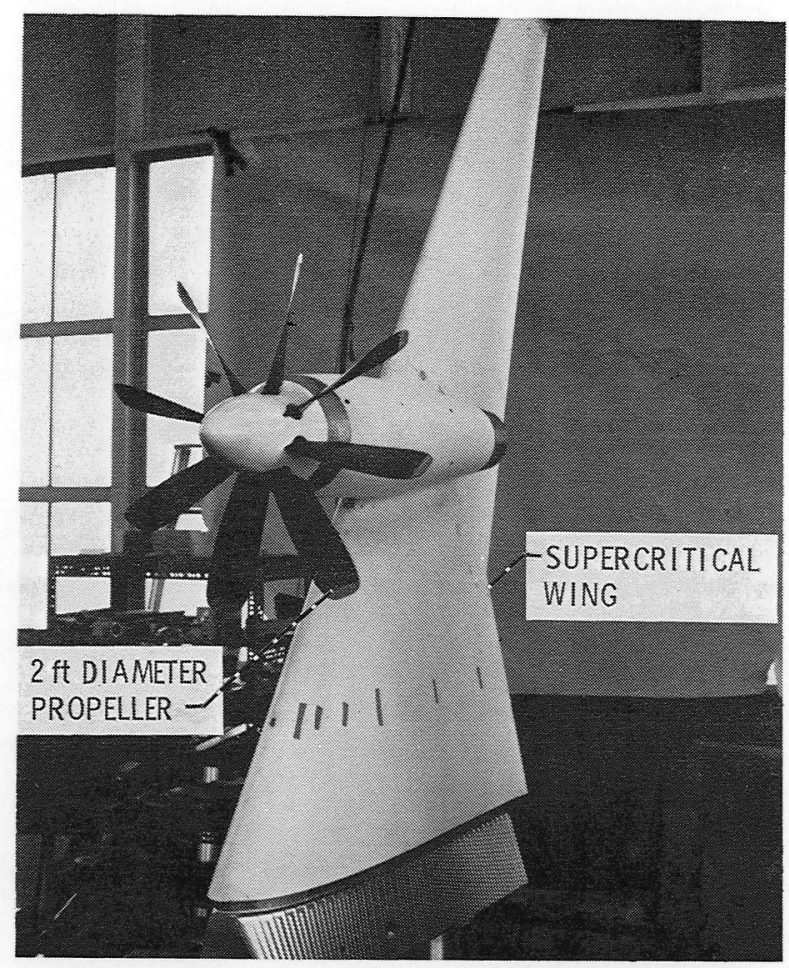

\begin{tabular}{|c|c|c|}
\hline & $\begin{array}{c}\text { SIMPLE GEOMETRIES } \\
\text { ROUGH CALCULATION }\end{array}$ & $\begin{array}{c}\text { COMPLEX GEOMETRIES } \\
\text { MORE DETAILED } \\
\text { CALCULATIONS }\end{array}$ \\
\hline $\begin{array}{c}\text { LINEAR PANEL } \\
\text { CODE } \\
(M \leq 0.65)\end{array}$ & $\begin{array}{c}\text { HESS CODE } \\
\text { (CURRENT) } \\
\text { DOUGLAS }\end{array}$ & $\begin{array}{c}\text { PANAIR CODE } \\
\text { (IN DEVELOPMENT) } \\
\text { BOEING }\end{array}$ \\
\hline $\begin{array}{c}\text { TRANSONIC } \\
\text { PANEL CODE }\end{array}$ & $\begin{array}{c}\text { WING/SLIPSTREAM } \\
\text { (CURRENT) } \\
\text { FLOW RESEARCH }\end{array}$ & $\begin{array}{c}\text { HYBRID CODE } \\
\text { (IN DEVELOPMENT) }\end{array}$ \\
\hline
\end{tabular}

Figure 30. - Analyses used in prediction of propeller slipstream/wing/ nacelle aerodynamic interactions.

Figure 29. - Wing, nacelle, and propeller for powered semi-span model test in Ames 14-Foot Wind Tunnel. 


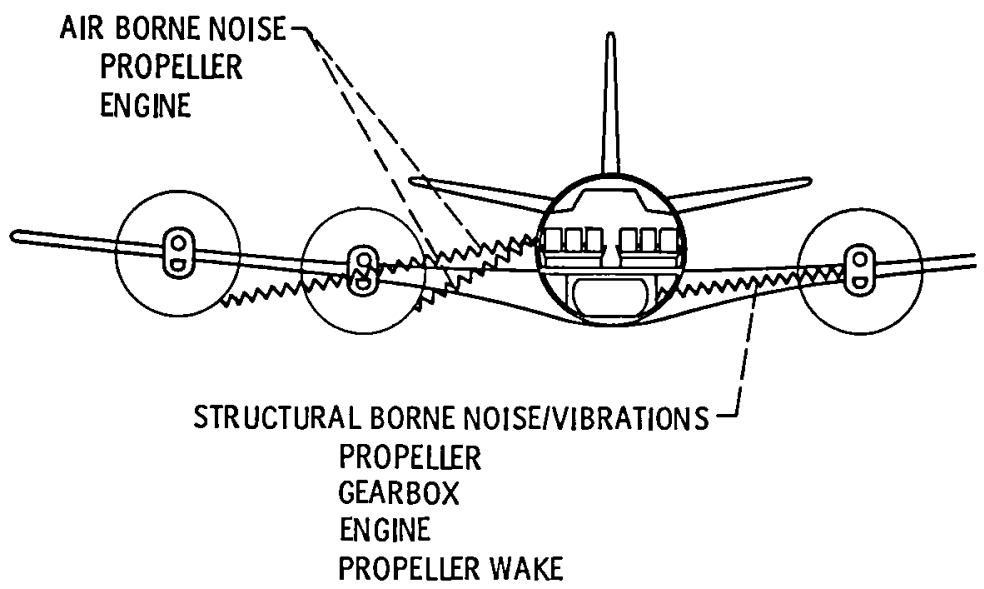

Figure 31. - Potential sources of passenger cabin noise and vibration.

- design PROPELLER fOR LOW NOISE Generation

- DESIGN FUSELAGE WALL FOR LARGE NOISE REDUCTION

- SELECT CABIN FURNISHINGS AND CONFIGURATION FOR LOW NOISE

- SYNCHROPHASE PROPELLERS - ELIMINATE BEATS AND LOWER NOISE/VIBRATION

- MINIMIZE PROPELLER UNBALANCE AND DYNAMIC AIR LOADING

- DESIGN AND TUNE ENGINE MOUNTS FOR VIBRATION ISOLATION

- taILOR WING CONTOUR AND STRUCTURE FOR LOW RESPONSE TO PROPELLER WAKE

- OPTIMIZE AIRCRAFT CONFIGURATION

- ENGINE PLACEMENT - WING OR AFT FUSELAGE

- TAIL SURFACES NOT IN PROPELLER WAKE FOR WING MOUNTED ENGINES

Figure 32. - Techniques for reducing passenger cabin noise and vibration. 


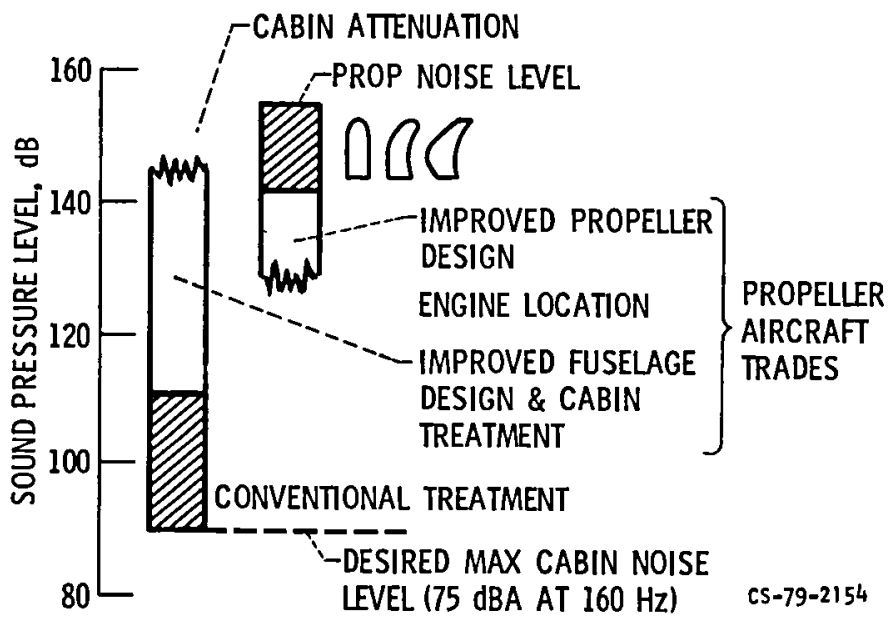

Figure 33. - Tradeoffs and approaches to achieve desired cabin noise level.

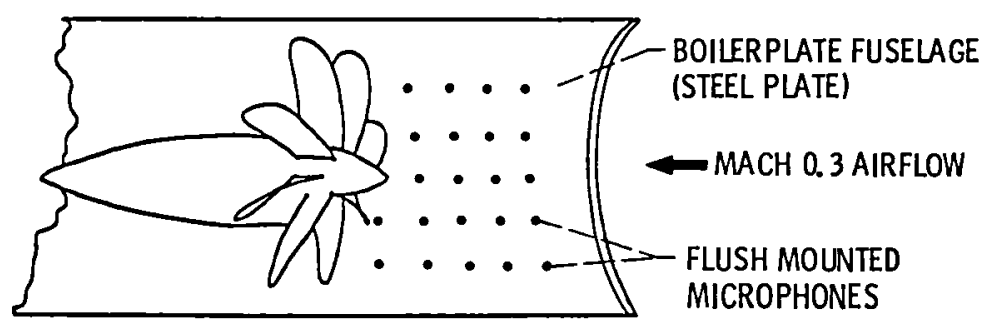

TEST MODEL

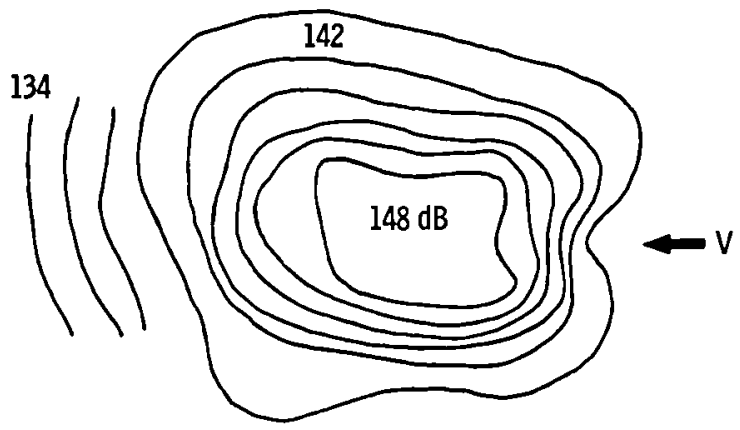

ISOSONIC CONTOURS

Figure 34. - Test of boilerplate fuselage at Mach 0.3. 
STUDY CONCLUSIONS:

INTERIOR CABIN NOISE GOAL OF 80 dBA APPEARS ACHIEVABLE WITH CONVENTIONAL ALUMINUM FUSELAGE STRUCTURE DOUBLE WALL CONCEPT IDENTIFIED AS MOST ATTRACTIVE EXPERIMENTAL VALIDATION REQUIRED
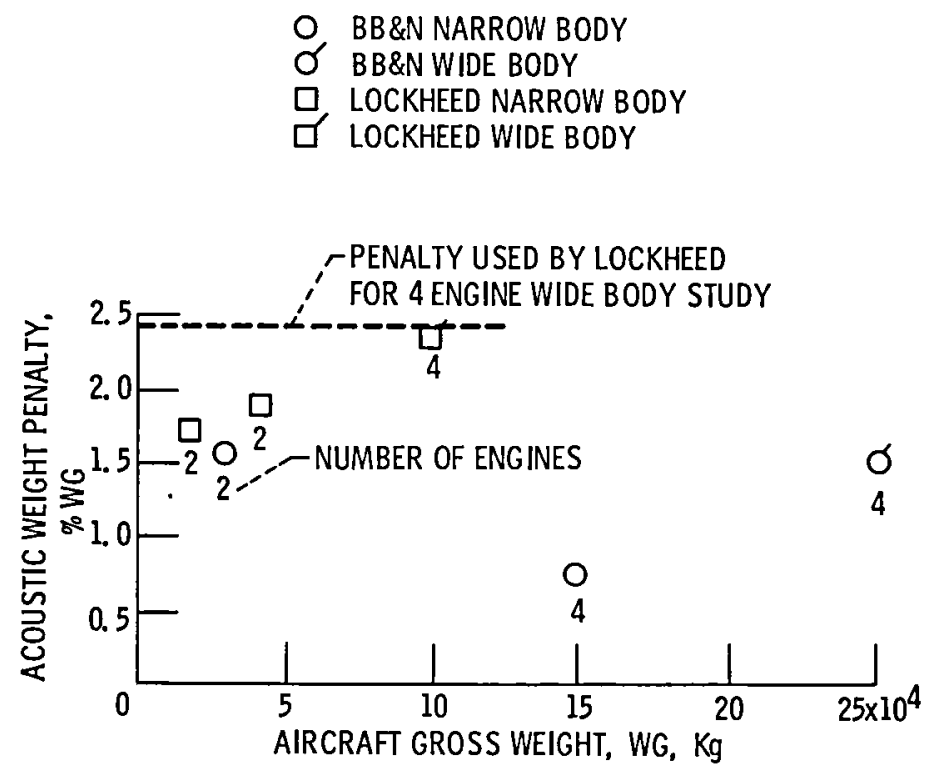

Figure 35. - Fuselage acoustic sidewall design and estimated aircraft weight penalty. Results of studies by Bolt Beranek and Newman Inc., and the Lockheed California Company.

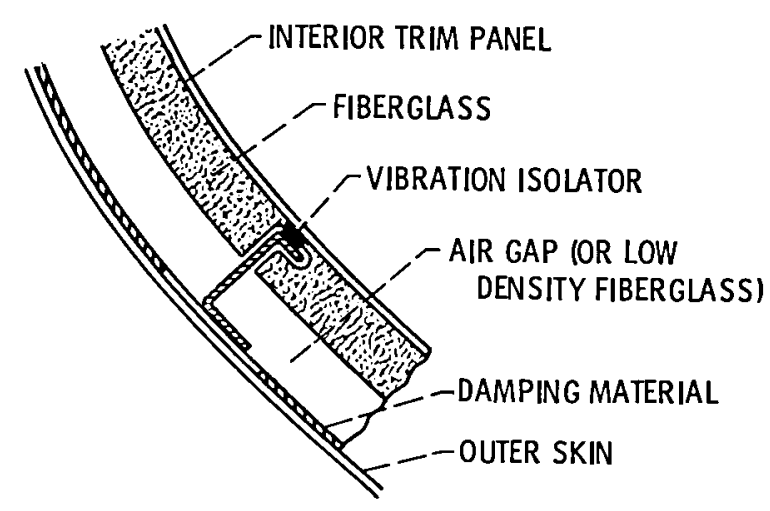

DOUBLE WALL CONCEPT USES OPTIMUM COMBINATION OF MASS, DENSITY, STIFFNESS, AND DAMPING

Figure 36. - Double wall fuselage design concept. 
RELATIVE TO TURBOFAN-POWERED AIRCRAFT WITH

SAME LEVEL OF CORE TECHNOLOGY

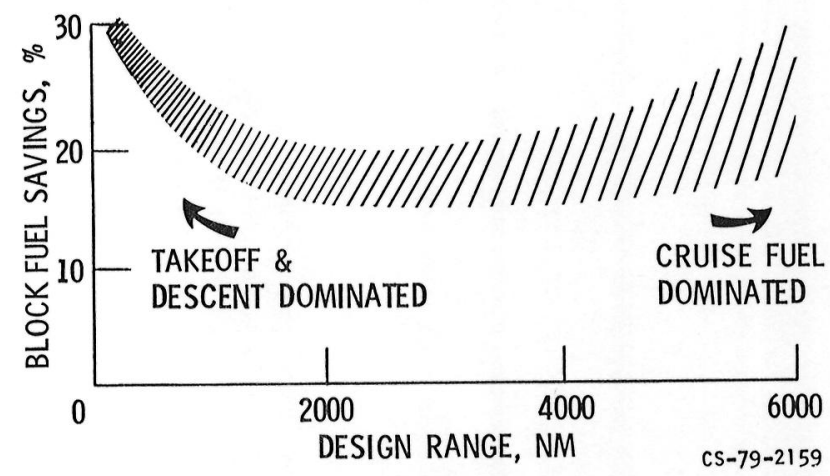

Figure 37. - Trend of potential fuel savings for advanced turboprop-powered aircraft.

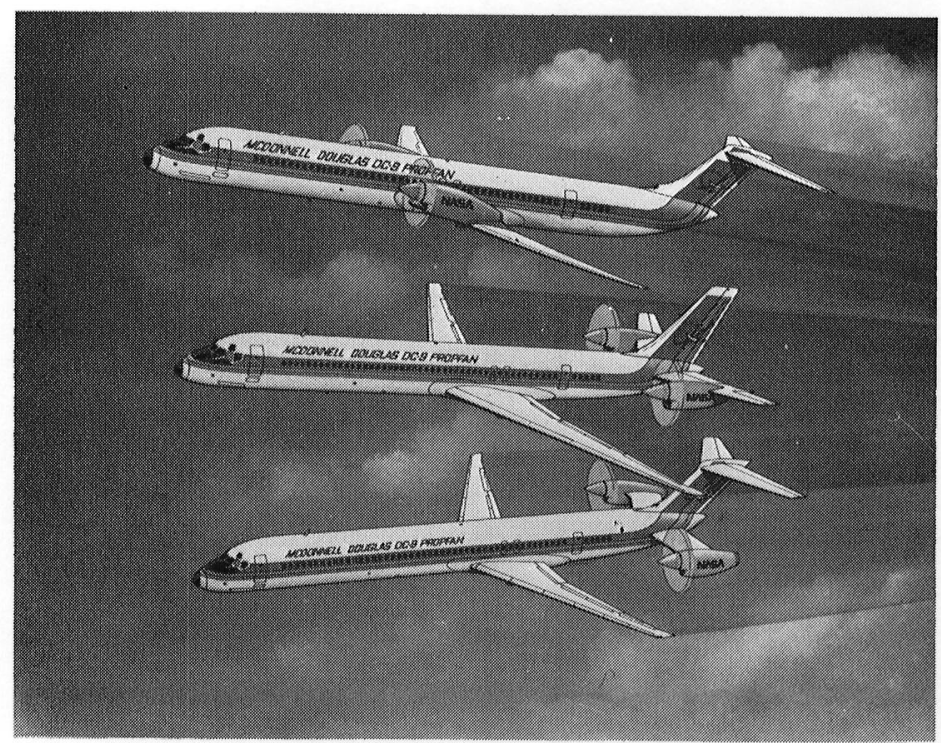

Figure 38. - DC -9 Super 80 turboprop derivative aircraft. 


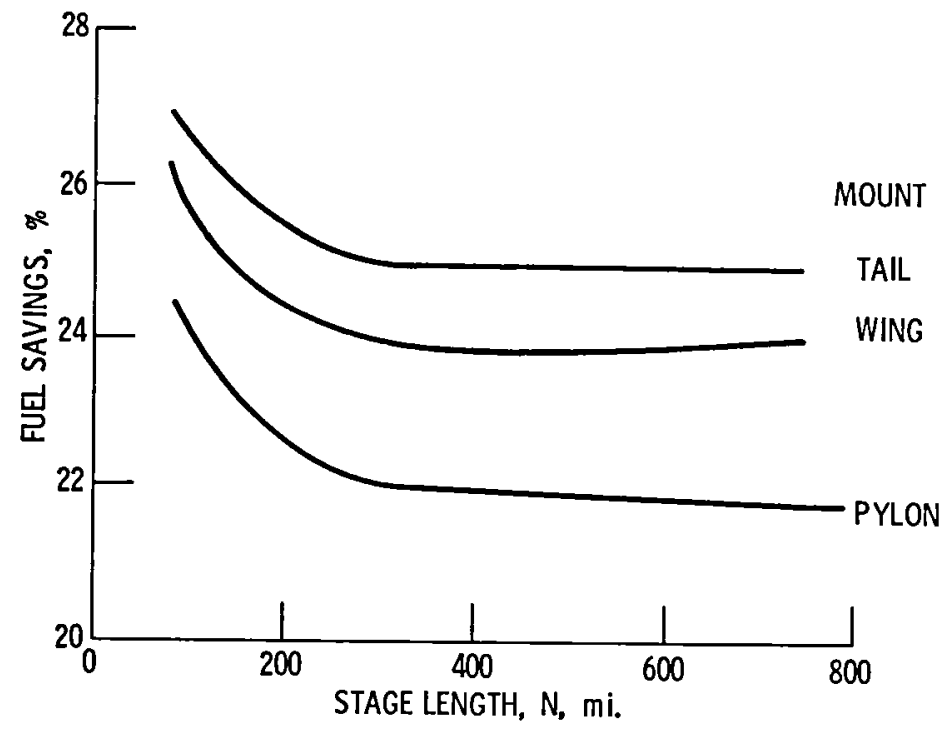

Figure 39. - Turboprop feasibilty study results - DC-9 super 80.

1960 ERA TURBOPROP MAINTENANCE COSTS HIGHER THAN JT8D DIFFERENCE MAINLY IN CORE ENGINE

ADVANCED TURBOPROP CAN BE COMPETITIVE WTH ADVANCED TURBOFAN

EQUAL CORE COSTS

PROPELLER \& GEARBOX GREATLY IMPROVED

- ELIMINATE SCHEDULED OVERHAULS

- USE modULAR construction

- SIMPLER, MORE RELIABLE DESIGN

Figure 40 - Reliability and maintenance cost study. Contract NAS3-20057 (Detroit Diesel Allison). 


\begin{tabular}{|c|c|c|c|c|c|c|c|c|c|c|c|}
\hline PROGRAM PHASING & 78 & 79 & 80 & 81 & 82 & 83 & 84 & 85 & 86 & 87 & 88 \\
\hline \multicolumn{12}{|l|}{ PHASE I - ENABLING TECHNOLOGY } \\
\hline \multicolumn{12}{|l|}{$\begin{array}{l}\text { SUB-SCALE MODEL TESTS \& ANALYSIS } \\
\text { AERO/ACOUSTIC METHODOLOGY }\end{array}$} \\
\hline \multicolumn{12}{|l|}{ PHASE II - LARGE SCALE STRUCTURES } \\
\hline \multicolumn{12}{|l|}{ BLADE AND DISK TECHNOLOGY } \\
\hline \multicolumn{12}{|l|}{ PROPELLER DRIVE SYSTEM } \\
\hline \multicolumn{12}{|l|}{ GROUND TESTS - STATIC AND W.T. } \\
\hline \multirow{2}{*}{\multicolumn{12}{|c|}{ FUSELAGE ACOUSTICS ANALYSIS/TESTS }} \\
\hline \multicolumn{7}{|l|}{ INSTALLATION AERODYNAMICS } & & & & & \\
\hline \multicolumn{12}{|l|}{$\begin{array}{l}\text { ADVANCED GEARBOX \& PITCH CHANGE } \\
\text { PRELIM. DES. IENG INE STUDIES }\end{array}$} \\
\hline \multicolumn{12}{|l|}{ PHASE III - SYSTEMS INTEGRATION } \\
\hline \multicolumn{12}{|l|}{$\begin{array}{l}\text { TEST AIRCRAFT DESIGN/MODIFY STRUCTURESI } \\
\text { AERODYNAMICSIACOUSTICS }\end{array}$} \\
\hline \multicolumn{12}{|l|}{ FLIGHT RESEARCH TESTS } \\
\hline ADVANCED G.B. \& P.C. DES. IFAB/TESTS & & & & & & & & & & & \\
\hline
\end{tabular}

Figure 4l. - Summary overview of Advanced Turboprop Project as now planned.

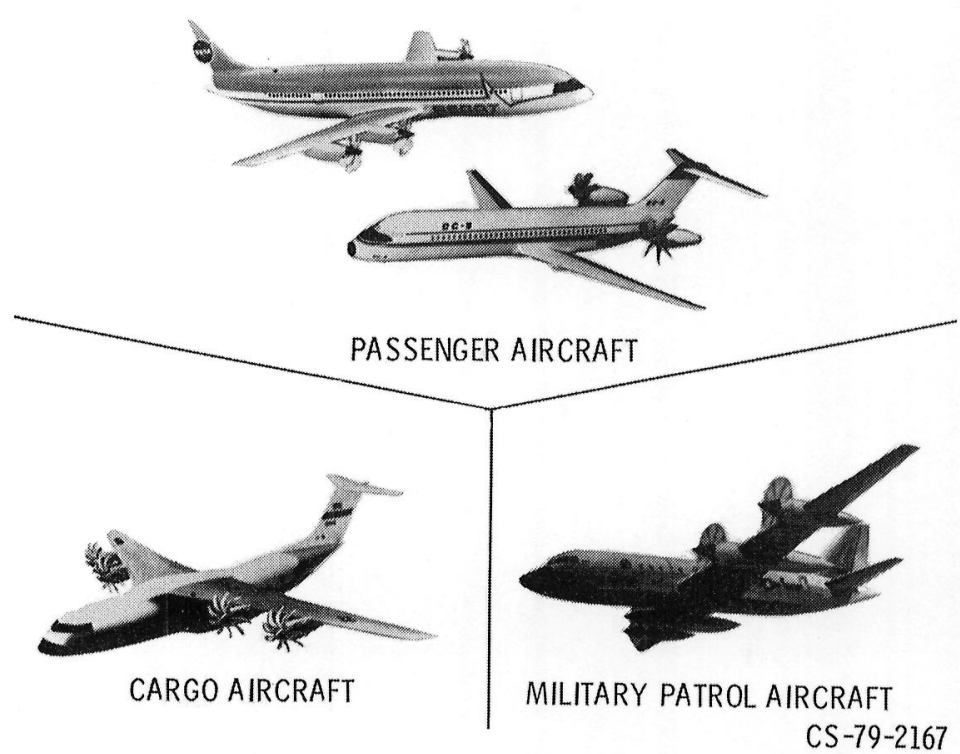

Figure 42. - Advanced turboprop aircraft concepts. 


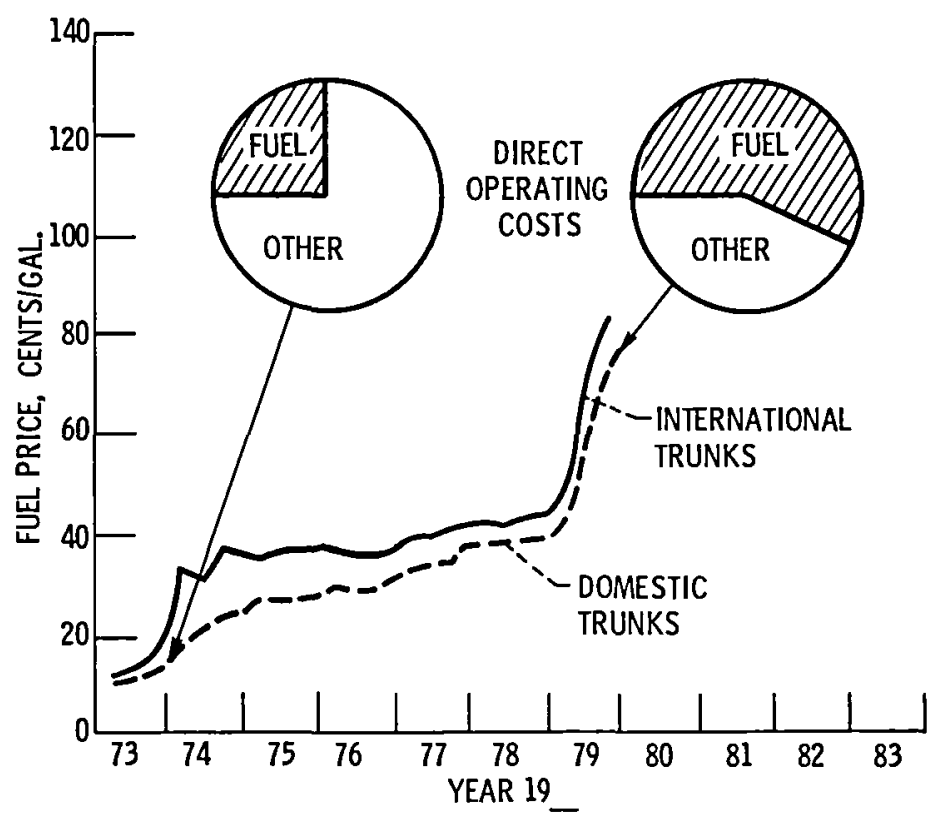

Figure 43. - U. S. Airline jet fuel price monthly averages. CAB data. 


\begin{tabular}{|c|c|c|c|}
\hline $\begin{array}{l}\text { 1. Report No. } \\
\text { NASA TM-81561 }\end{array}$ & 2. Government Accession No. & \multicolumn{2}{|c|}{ 3. Recipient's Catalog No. } \\
\hline \multirow{2}{*}{\multicolumn{2}{|c|}{$\begin{array}{l}\text { 4. Title and Subtitle } \\
\text { THE NASA HIGH-SPEED TURBOPROP PROGRAM }\end{array}$}} & \multicolumn{2}{|l|}{ 5. Report Date } \\
\hline & & \multicolumn{2}{|c|}{ 6. Performing Organization Code } \\
\hline \multicolumn{2}{|c|}{ 7. Author(s) } & \multicolumn{2}{|c|}{$\begin{array}{l}\text { 8. Performing Organization Report No. } \\
\text { E-452 }\end{array}$} \\
\hline \multicolumn{2}{|c|}{$\begin{array}{l}\text { James F. Dugan, Brent A. Miller, Edwin J. Graber, } \\
\text { and David A. Sagerser }\end{array}$} & \multirow{2}{*}{\multicolumn{2}{|c|}{ 10. Work Unit No. }} \\
\hline \multirow{3}{*}{\multicolumn{2}{|c|}{$\begin{array}{l}\text { 9. Performing Organization Name and Address } \\
\text { National Aeronautics and Space Administration } \\
\text { Lewis Research Center } \\
\text { Cleveland, Ohio } 44135\end{array}$}} & & \\
\hline & & \multicolumn{2}{|c|}{ 11. Contract or Grant No. } \\
\hline & & \multirow{2}{*}{\multicolumn{2}{|c|}{$\begin{array}{l}\text { 13. Type of Report and Period Covered } \\
\text { Technical Memorandum }\end{array}$}} \\
\hline \multirow{2}{*}{\multicolumn{2}{|c|}{$\begin{array}{l}\text { 12. Sponsoring Agency Name and Address } \\
\text { National Aeronautics and Space Administration } \\
\text { Washington, D. C. } 20546\end{array}$}} & & \\
\hline & & \multicolumn{2}{|c|}{ 14. Sponsoring Agency Code } \\
\hline \multicolumn{4}{|c|}{$\begin{array}{l}\text { 15. Supplementary Notes } \\
\text { Prepared for the Aerospace Congress sponsored by the American Society of Automotive } \\
\text { Engineers, Los Angeles, California, October 13-16, 1980. }\end{array}$} \\
\hline \multicolumn{4}{|c|}{$\begin{array}{l}\text { 16. Abstract } \\
\text { NASA's Advanced Turboprop Project is a three phased effort initiated in } 1978 \text { to provide tech- } \\
\text { nology readiness for Mach } 0.7 \text { to } 0.8 \text { turboprop-powered aircraft with the potential for fuel } \\
\text { savings and DOC reductions of up to } 30 \text { and } 15 \text { percent respectively relative to current in-service } \\
\text { aircraft. This paper reviews the status of Phase I in the areas of propeller aeroacoustics, pro- } \\
\text { peller structures, turboprop installed perfor mance, aircraft cabin environment, and turboprop } \\
\text { engine and aircraft studies. Current plans to establish large-scale propeller characteristics } \\
\text { and to conduct high-speed propeller flight research tests using a modified testbed aircraft are } \\
\text { also presented. }\end{array}$} \\
\hline $\begin{array}{l}\text { 17. Key Words (Suggested by Author(s)) } \\
\text { Turboprop } \\
\text { Propeller } \\
\text { Commercial aircraft }\end{array}$ & $\begin{array}{l}\text { 18. Distrib } \\
\text { Uncle } \\
\text { STA }\end{array}$ & unlimited & \\
\hline $\begin{array}{l}\text { 19. Security Classif. (of this report) } \\
\text { Unclassified }\end{array}$ & $\begin{array}{l}\text { 20. Security Classif. (of this page) } \\
\text { Unclassified }\end{array}$ & 21. No, of Pages & 22. Price" \\
\hline
\end{tabular}

* For sale by the National Technica! Information Service, Springfield, Virginia 22161 
National Aeronautics and Space Administration

Washington, D.C.

20546

Official Business

Penalty for Private Use, $\$ 300$
$\mathbf{L}$

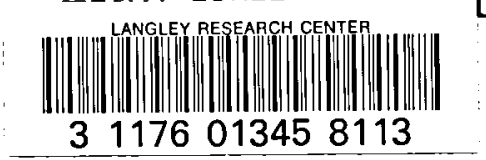

Postage and Fees Paid

National, Aeronautics and

Space Administration

NASA-45

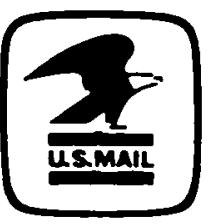

\section{N/SN}

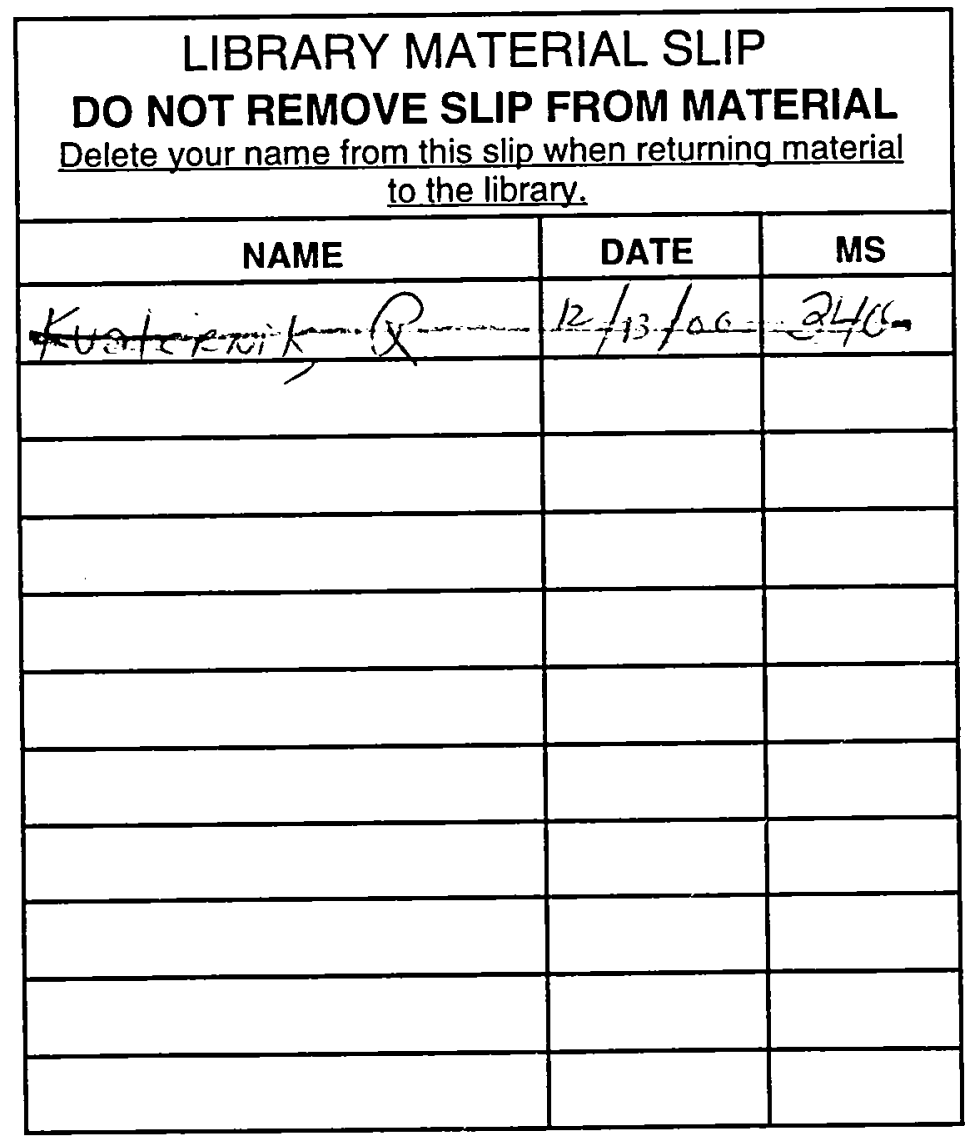

Undeliverable (Section 158 stal Manual) Do Not Return

NASA Langley Form 474 (Rev. Oct. 1999) 